University of Nebraska - Lincoln

DigitalCommons@University of Nebraska - Lincoln

\title{
Geochemical evidence for airborne dust additions to soils in Channel Islands National Park, California
}

\author{
Daniel R. Muhs \\ U.S. Geological Survey, dmuhs@usgs.gov \\ James R. Budahn \\ U.S. Geological Survey \\ Donald L. Johnson \\ University of Illinois \\ Marith Reheis \\ U.S. Geological Survey \\ Jossh Beann \\ U.S. Geological Survey
}

See next page for additional authors

Follow this and additional works at: https://digitalcommons.unl.edu/usgsstaffpub

Part of the Earth Sciences Commons

Muhs, Daniel R.; Budahn, James R.; Johnson, Donald L.; Reheis, Marith; Beann, Jossh; Skipp, Gary; Fischer, Eric; and Jones, Julia A., "Geochemical evidence for airborne dust additions to soils in Channel Islands National Park, California" (2008). USGS Staff -- Published Research. 160.

https://digitalcommons.unl.edu/usgsstaffpub/160

This Article is brought to you for free and open access by the US Geological Survey at DigitalCommons@University of Nebraska - Lincoln. It has been accepted for inclusion in USGS Staff -- Published Research by an authorized administrator of DigitalCommons@University of Nebraska - Lincoln. 


\section{Authors}

Daniel R. Muhs, James R. Budahn, Donald L. Johnson, Marith Reheis, Jossh Beann, Gary Skipp, Eric Fischer, and Julia A. Jones 


\title{
Geochemical evidence for airborne dust additions to soils in Channel Islands National Park, California
}

\author{
Daniel R. Muhs \\ James R. Budahn \\ U.S. Geological Survey, M.S. 980, Box 25046, Federal Center, Denver, Colorado 80225, USA
}

Donald L. Johnson

Department of Geography, University of Illinois, Urbana, Illinois 61801, USA

\author{
Marith Reheis \\ Jossh Beann \\ Gary Skipp \\ Eric Fisher \\ U.S. Geological Survey, M.S. 980, Box 25046, Federal Center, Denver, Colorado 80225, USA
}

Julia A. Jones

Department of Geosciences, 104 Wilkinson Hall, Oregon State University, Corvallis, Oregon 97331-5506, USA

\begin{abstract}
There is an increasing awareness that dust plays important roles in climate change, biogeochemical cycles, nutrient supply to ecosystems, and soil formation. In Channel Islands National Park, California, soils are clay-rich Vertisols or Alfisols and Mollisols with vertic properties. The soils are overlain by silt-rich mantles that contrast sharply with the underlying clay-rich horizons. Silt mantles contain minerals that are rare or absent in the volcanic rocks that dominate these islands. Immobile trace elements (Sc-Th-La and Ta-Nd-Cr) and rare-earth elements show that the basalt and andesite on the islands have a composition intermediate between upper-continental crust and oceanic crust. In contrast, the silt fractions and, to a lesser extent, clay fractions of the silt mantle have compositions closer to average upper-continental crust and very similar to Mojave Desert dust. Island shelves, exposed during the last glacial period, could have provided a source of eolian sediment for the silt mantles, but this is not supported by mineralogical data. We hypothesize that a more likely source for the silt-rich mantles is airborne dust from mainland California and Baja California, either from the Mojave Desert or from the continental shelf during glacial low stands of sea. Although average winds
\end{abstract}

*dmuhs@usgs.gov are from the northwest in coastal California, easterly winds occur numerous times of the year when "Santa Ana" conditions prevail, caused by a high-pressure cell centered over the Great Basin. The eolian silt mantles constitute an important medium of plant growth and provide evidence that abundant eolian silt and clay may be delivered to the eastern Pacific Ocean from inland desert sources.

Keywords: Silt mantles, dust, eolian, soils, marine terraces, volcanic rocks, California, Channel Islands National Park, Santa Cruz Island, Santa Barbara Island, Anacapa Island, mineralogy, geochemistry, trace elements, rare earths, Santa Ana winds.

\section{INTRODUCTION}

Dust plays important roles in many aspects of Earth's physical systems (Mahowald et al., 1999, 2006; Harrison et al., 2001; Kohfeld and Harrison, 2001). Because dust can travel intercontinental distances (Rea, 1994; Prospero et al., 2002; Prospero and Lamb, 2003), it can influence radiative transfers in the atmosphere and affect climate (Tegen, 2003). Iron-rich dust can fertilize the ocean's primary producers, such as phytoplankton (Jickells et al., 2005) and, consequently, can affect the global carbon cycle (Falkowski et al., 1998). Furthermore, dust may be important for plant communities in nutrient-limited ecosystems (Swap et al., 1992;
Reynolds et al., 2001, 2006; Muhs and Benedict, 2006).

Dust can form the parent material for soils or can influence soils that have developed from other parent materials (see Birkeland, 1999, for many examples). Yaalon and Ganor (1973) present a useful conceptual model of the importance of dust to soils, based on field criteria. They recognize four broad members in a continuum of varying eolian influence. At one extreme, soils develop completely from finegrained eolian sediment, such as loess. With a decreasing eolian influence, soils have developed in part from some other parent material, but such soils still have a substantial dust input. In fact, in this member of the continuum, eolian dust inputs are significant enough that not only have fine-grained eolian particles been added to the matrix of the original parent material, but also an eolian mantle is found in the upper part of the solum. Still less eolian influence can be seen frequently with soils that have received abundant fine-grained eolian inputs and have developed substantially from them, but these soils lack a purely eolian mantle in their upper parts. Finally, there are some soils that have evidence of eolian inputs that can be detected only by detailed mineralogical or geochemical studies, because the eolian influence is not apparent in the field. Yaalon and Ganor (1973) refer to such a condition as "eolian contamination," implying that while the eolian input can be identified and measured, it is secondary to

GSA Bulletin; January/February 2008; v. 120; no. 1/2; p. 106-126; doi: 10.1130/B26218.1; 18 figures; Data Repository Item 2007261. 
another parent material with regard to importance for pedogenesis.

Soil and Quaternary stratigraphic studies over the past few decades have identified good examples of the extreme end members of the dustsoil continuum of Yaalon and Ganor (1973). Thick loess deposits of China, Europe, New Zealand, South America, and North America are obvious examples of parent material for soils developed entirely from a fine-grained eolian sediment. At the other extreme, there are also good examples of "eolian contamination" of soils, from both short-range and long-range transportation. Basalt-hosted soils of Victoria, Australia, contain quartz, which must be derived from an external source (Jackson et al., 1972). Long-range eolian transport of exotic particles, such as Asian quartz in basalt-derived soils of Hawaii, is well documented (Rex et al., 1969).

There are fewer examples of the intermediate members of the Yaalon and Ganor (1973) dust-soil continuum. Exceptions to this include the rapidly accumulating evidence that much of the carbonate and clay in desert soils may be of eolian origin, despite the absence of an obvious eolian mantle. In many arid regions, calcic, petrocalcic, and argillic horizons may be derived largely from eolian inputs of carbonate and clay. Studies in desert areas of New Mexico, Nevada, and California, for example, have demonstrated that both clay-rich and carbonate-rich soil horizons in desert soils owe their origins to substantial additions of eolian particles (Gile and Grossman, 1979; Reheis et al., 1995). Australia also has many examples of soils developed mostly in eolian particles, but without an obvious eolian mantle (see Hesse and McTainsh, 2003), and similar interpretations have been made for soils and paleosols on Bermuda (Herwitz et al., 1996).

There is also a growing recognition of finegrained eolian silt mantles in the upper parts of soils that have developed in or on some other substrate. Quaternary deposits of many highmountain areas, such as till, rock glacier deposits, and talus, are often characterized by silt mantles interpreted to be of eolian origin (see review in Muhs and Benedict, 2006). Silt or loess mantles have been described at the margins of, or even outside of the major loess belts of China (Sun, 2002), Europe (Coudé-Gaussen, 1990), New Zealand (Eden and Hammond, 2003), South America (Zárate, 2003), and North America (Muhs et al., 2004a).

Eolian silt mantles have been described from arid and semi-arid regions well away from major loess regions of mid-latitudes. For example, African-dust-derived silt mantles have been described and mapped on parts of the basalt terrains of the Canary Islands (Rognon and
Coudé-Gaussen, 1987), and thicker paleosol sequences on these islands may have similar origins (Zöller et al., 2003, 2004). In many parts of the Mojave Desert in California, there are numerous occurrences of silt-rich eolian mantles on basaltic volcanic flows or alluvial fan deposits of variable lithologies (Wells et al., 1985; McFadden et al., 1986, 1998; Reheis et al., 1995; Anderson et al., 2002). The Mojave Desert silt mantles commonly have numerous vesicles and are often referred to as "vesicular horizons" or "Av" horizons. Along with clay-rich Australian loess, or "parna" (Hesse and McTainsh, 2003), the silt mantles of the Canaries and the Mojave may be some of the best examples of what has been called "desert loess," or eolian silt that does not have a glaciogenic origin.

Several of the Channel Islands, off the coast of California (Fig. 1), have soils developed on volcanic substrates, mainly Miocene andesite and basalt. Muhs (1983) reported silt mantles, interpreted to be of eolian origin, on marine terraces cut into andesite on San Clemente Island. A recent reexamination of these features on San Clemente Island confirms that they are likely eolian and are derived from a source external to the island (Muhs et al., 2007b). On Santa Cruz Island, within Channel Islands National Park, Butterworth et al. (1993) reported that many soil A horizons are characterized by siltloam textures, despite clay-rich subsoils. If the surface horizons of soils on these two islands, $\sim 200 \mathrm{~km}$ apart, are of eolian origin, this suggests that fine-grained, airborne dust additions may be a regionally important process in coastal southern California. In the present study, we undertook an investigation of soils on three of the islands in Channel Islands National Park to test this hypothesis. The issue is an important one, because these islands have a long history of soil erosion from the introduction of grazing animals by nineteenth century ranchers (Johnson, 1980). Furthermore, the upper horizons of soils in Channel Islands National Park are the media of growth for numerous endemic or near-endemic plants, many of which are rare or endangered (Schoenherr et al., 1999).

\section{USE OF TRACE-ELEMENT GEOCHEMISTRY IN SOIL OR SEDIMENT ORIGINS (PROVENANCE)}

Our primary method in this study is to use relatively immobile trace elements as "fingerprints" for source materials, following an approach we have used in studying eolian sediments in Alaska, western Atlantic islands, and elsewhere in California (see Muhs and Budahn, 2006; Muhs et al., 2007a, 2007b, and references therein). Certain trace elements in rocks, sediments, and soils are very useful for provenance studies. We chose two suites of relatively immobile elements, Sc-Th-La and Ta-Nd-Cr. These elements, when arrayed on ternary plots, show clearly separated compositional fields for oceanic crust and upper continental crust (e.g., Taylor and McLennan, 1985, p. 29). If the particles in the silt mantles are locally derived, they should plot within the basalt or andesite fields of the local bedrock. If the mantles are dominantly dust particles derived from an external source, the silt particles will likely have a composition that falls on or close to that of upper-continental crust.

The rare-earth elements (REE), La through $\mathrm{Lu}$, also can be valuable as provenance indicators. The upper-continental crust (UCC) has a distinctive composition with regard to REE (Taylor et al., 1983; McLennan 1989; Taylor and McLennan, 1985, 1995). On chondritenormalized REE plots, sediments from the UCC are characterized by enriched light REE, a negative Eu anomaly, and depleted heavy REE (expressed on plots as a "flat" curve). Loesses from a variety of regions worldwide have a typical upper-crustal composition based on REE abundances (Taylor et al., 1983; Gallet et al., 1998; Jahn et al., 2001; Muhs and Budahn, 2006; Muhs et al., 2007a), as does modern dust collected in the southwestern United States (Reheis et al., 2002).

The suite of elements chosen, Sc, Th, Ta, Cr, and the REE, are hosted by a variety of minerals. The most likely host minerals for $\mathrm{Cr}$ and $\mathrm{Sc}$ are micas, amphiboles, and clay minerals. Th and $\mathrm{Ta}$ are found in micas, amphiboles, zircon, sphene, and clay minerals; in addition, Ta can be found in magnetite or ilmenite. The REE are usually hosted by micas, chlorite, clay minerals, amphiboles, sphene, zircon, monazite, apatite, and, in small amounts, feldspars.

\section{LABORATORY METHODS}

For particle-size analyses, samples were analyzed using a Malvern Mastersizer model MSSL [use of trade names is for descriptive purposes only and does not imply endorsement by the U.S. Geological Survey] laser particle-size instrument. Prior to analysis, the silt mantle samples were treated with hydrogen peroxide to remove organic matter and dilute $(\sim 20 \%) \mathrm{HCl}$ to remove carbonates. Sodium hexametaphosphate was then added as a dispersant and left overnight. Following this procedure, samples were treated by ultrasonic shaking to aid dispersion of clays. The same method was used for selected samples of Mojave Desert dust, at localities described in Reheis and Kihl (1995), Reheis et al. (2002), 


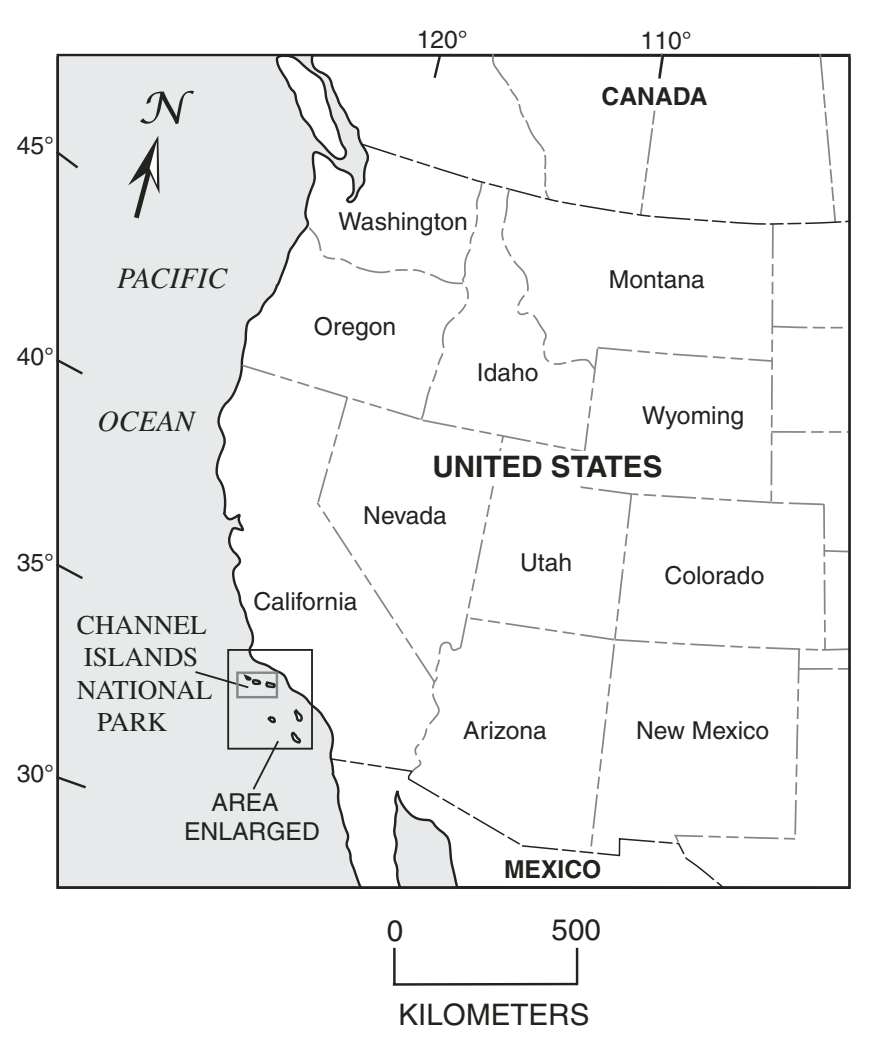

Figure 1. Left: map of the western United States, showing location of Channel Islands National Park. Right: enlargement of study area shown in larger map, showing coastal southern California, Channel Islands National Park, and the southern group of Channel Islands.

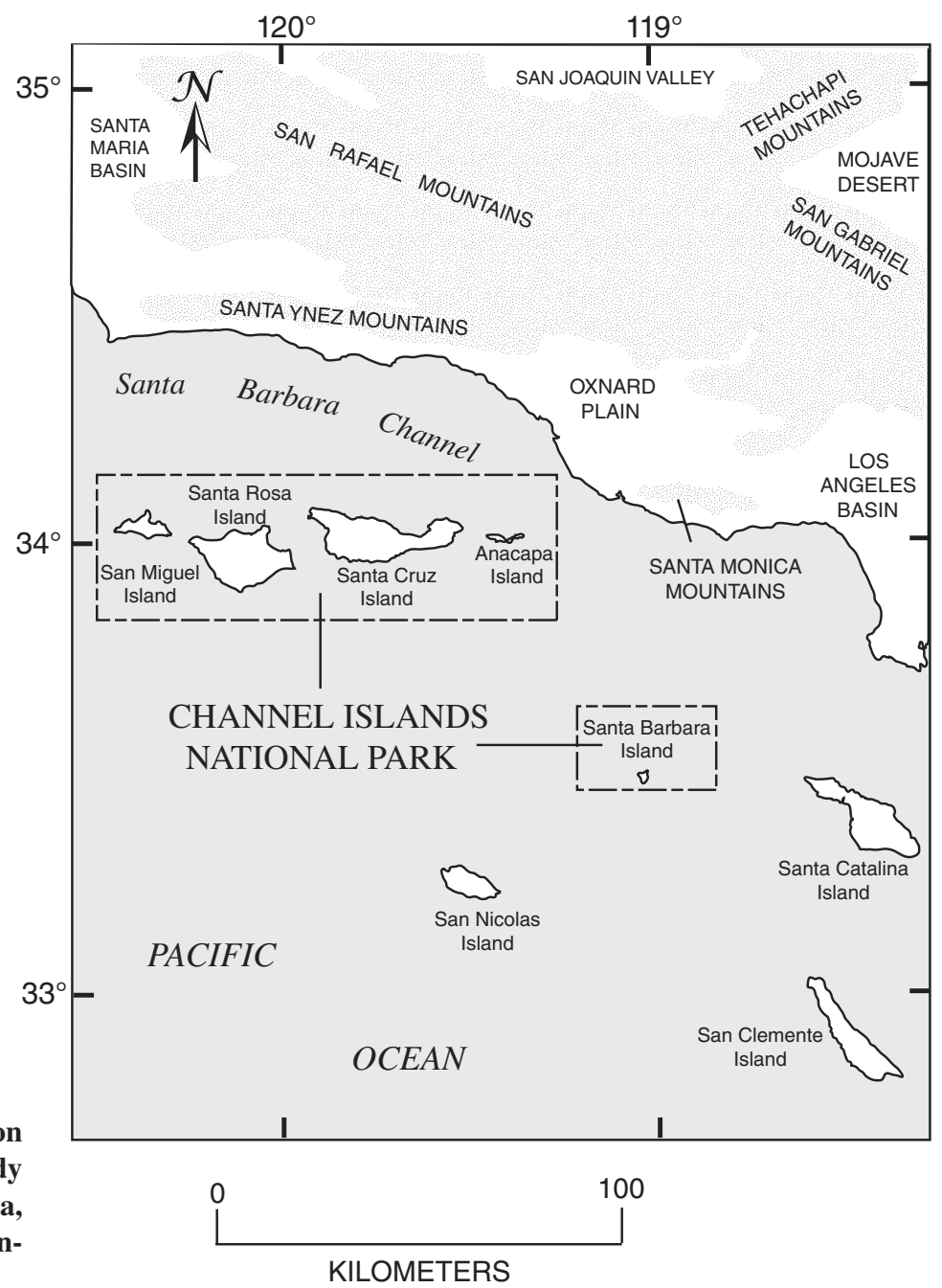

KILOMETERS and Reheis (2003, 2006). The Mojave Desert samples described in these papers and used in this study consist of deposited (as opposed to suspended) dust-trap samples, dominated by silt-sized particles. In comparisons of particle sizes of Channel Islands silt mantles with other eolian sediments, we use only those data that have been generated by the laser particle-size method, similar to that used in our laboratory (e.g., Muhs and Benedict, 2006).

Prior to geochemical analyses, sands, silts, and clays in the silt mantles were fractionated and analyzed separately. The same pretreatments used for the particle-size analyses were used for these separations, except that $\mathrm{HCl}$ was not used. To obtain different size fractions, sands were removed by wet sieving $(53-\mu \mathrm{m}$ sieve), and repeated settling and decantation segregated clays and silts. We chose to make the sand-silt break at $53 \mu \mathrm{m}$, because this is closest to the conventional boundary $(50 \mu \mathrm{m})$ used in soil science for sands versus silts.
Because fine-grained volcanic rocks dominate the bedrock of the three islands, classification of the rock types and inferences about mineralogy were determined by major-element analyses using wavelength-dispersive X-ray fluorescence. In addition, however, bulk mineralogy of the volcanic bedrock and the silt $(53-2 \mu \mathrm{m})$ fractions of the silt mantles was determined by X-ray diffraction (XRD). We also determined the mineralogy of the clay $(<2 \mu \mathrm{m})$ fractions of the silt mantles by XRD on oriented samples using three treatments-air-dry, glycolated, and heat-treated $\left(550{ }^{\circ} \mathrm{C}\right)$.

Concentrations of low-mobility trace elements in both soils and pulverized island bedrock samples were determined by instrumental neutron-activation analysis (INAA), as described by Budahn and Wandless (2002). INAA in U.S. Geological Survey laboratories was also used for samples of Mojave Desert dust (Reheis et al., 2002; Reheis, 2003), and permits easy comparison with our data.

\section{GEOLOGY AND GEOMORPHOLOGY OF EASTERN CHANNEL ISLANDS NATIONAL PARK}

\section{Bedrock Geology}

Miocene volcanic rocks dominate the bedrock geology of the easternmost Channel Islands (Santa Barbara Island, the three Anacapa Islands, and eastern Santa Cruz Island). These rocks are part of a series of extensive Miocene volcanic rocks found in much of southern California (Weigand and Savage, 2002; Weigand et al., 2002). Weigand (1993), Weigand et al. (1998), and Weigand and Savage (2002) have conducted the most extensive geochemical studies of the volcanic rocks of the Channel Islands. Weigand and Savage (2002) conclude that Miocene magmas in southern California, including those on the Channel Islands, are the result of decompression melting in response to extension, which is, in turn, a function of tectonic rotation 


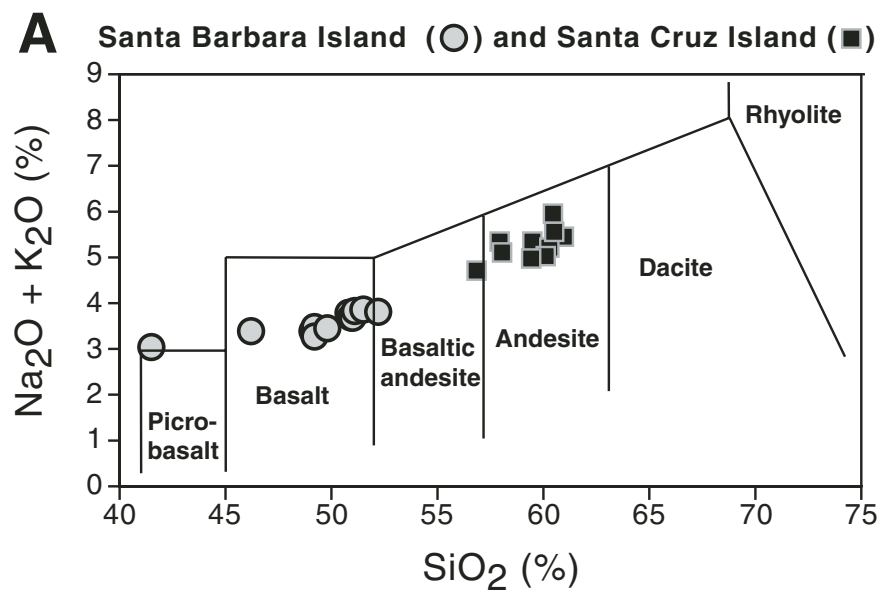

Figure 2. Classification of volcanic rocks on the Channel Islands as a function of $\mathrm{SiO}_{2}$ versus $\mathrm{Na}_{2} \mathrm{O}+\mathrm{K}_{2} \mathrm{O}$, using the classification scheme of Le Bas et al. $(1986,1992)$. All data are from this study.

\section{B East Anacapa Island}

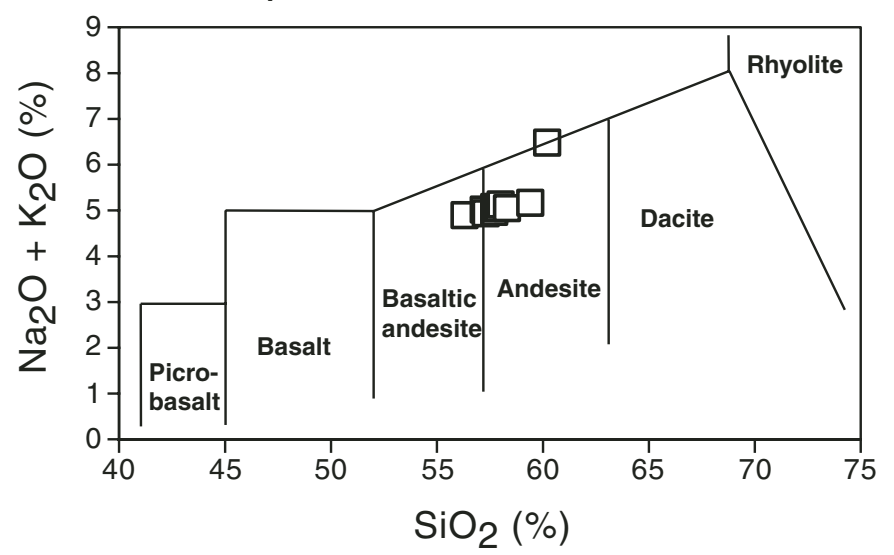

\section{San Clemente Island}

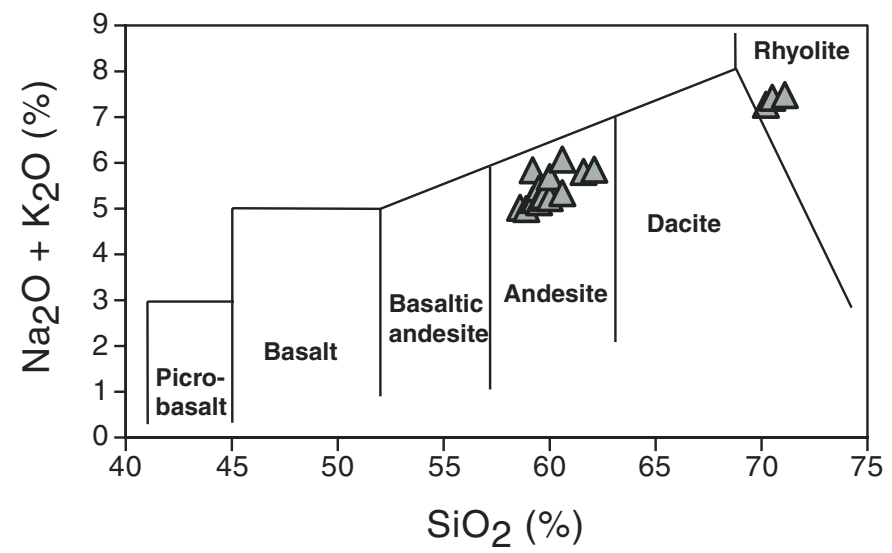

of the western Transverse Ranges crustal block. This igneous activity probably began ca. $19 \mathrm{Ma}$, was widespread by ca. $17 \mathrm{Ma}$, and diminished ca. $13 \mathrm{Ma}$, based on ${ }^{40} \mathrm{Ar} /{ }^{39} \mathrm{Ar}$ ages reported by Luyendyk et al. (1998).

Santa Cruz Island is the largest of the Channel Islands and has a much more complex geology than any of the other islands. Nevertheless, the geology of the easternmost part of the island, where our studies were conducted, is similar to that of Anacapa Island. The bedrock in our study area is dominated by the Santa Cruz Island Volcanics of Miocene age (Dibblee, 2001b), with whole-rock (groundmass separate) ${ }^{40} \mathrm{Ar} /{ }^{39} \mathrm{Ar}$ ages of $17.1 \pm 0.1$ and $16.3 \pm 0.3 \mathrm{Ma}$ and plagioclase ${ }^{40} \mathrm{Ar} /{ }^{39} \mathrm{Ar}$ ages of $16.9 \pm 0.2$ and 17.0 $\pm 0.1 \mathrm{Ma}$ (Luyendyk et al., 1998). Chemical analyses presented by Weigand (1993) and Weigand and Savage (2002) show that the Santa Cruz Island Volcanics range in composition from basaltic andesite to dacite, although all the samples we collected (DR ${ }^{1)}$ at Scorpion Anchorage are andesite (Fig. 2). Unlike Santa Barbara and Anacapa Islands, the Miocene Monterey Formation overlies the volcanic rocks of parts of eastern Santa Cruz Island (Dibblee, 2001b). The Monterey Formation is siliceous marine shale that also contains bentonite, carbonate nodules, and marine fossils. Based on Dibblee's (2001b) mapping, the Monterey Formation, in many places, appears to be in fault contact with the Santa Cruz Island Volcanics along a series of northwest-trending faults.

Volcanic rocks dominate Anacapa Island's bedrock. Mapping by Scholl (1960) and Dibblee (2001a) shows that the rocks consist of the Santa Cruz Island Volcanics and/or the Conejo Volcanics units of middle Miocene age. On Middle and West Anacapa Islands, there are also beds of the San Onofre Breccia (Norris, 1995). Although previous researchers have not reported it, we found very small outcrops of San Onofre

${ }^{1}$ GSA Data Repository Item 2007261, Major and trace element concentrations of volcanic rocks, trace element concentrations of silt mantles, and particle size data of silt mantles, Channel Islands National Park, California, is available at www.geosociety.org/ pubs/ft2007.htm. Requests may also be sent to editing@geosociety.org.
Breccia exposed on the west side of Cathedral Cove on East Anacapa Island. This unit contains clasts of quartzite or vein quartz, blueschist, shale, and sandstone. Chemical analyses presented here (Fig. 2) and by Weigand and Savage (2002) show that rocks on Anacapa Island are mostly andesites. Luyendyk et al. (1998) report ${ }^{40} \mathrm{Ar} /{ }^{39} \mathrm{Ar}$ ages on plagioclase separates from Anacapa rocks of $16.2 \pm 0.2$ and $16.3 \pm 0.2 \mathrm{Ma}$.

Santa Barbara Island is composed almost completely of mafic volcanic rocks (Dibblee, 2001a). Chemical analyses presented here, and by Weigand et al. (1998) and Weigand and Savage (2002), show that the rocks range in composition from basalt to andesite (Fig. 2). We collected 15 samples from exposures near Landing Cove. A whole-rock, ${ }^{40} \mathrm{Ar} /{ }^{39} \mathrm{Ar}$ age from basalt on Santa Barbara Island is $15.5 \pm 1.0 \mathrm{Ma}$ (Luyendyk et al., 1998).

\section{Quaternary Geology and Geomorphology}

Marine terraces dominate the geomorphology of low-elevation portions of eastern Santa Cruz Island (Fig. 3A). Terraces are also found 


\section{A Santa Cruz Island}

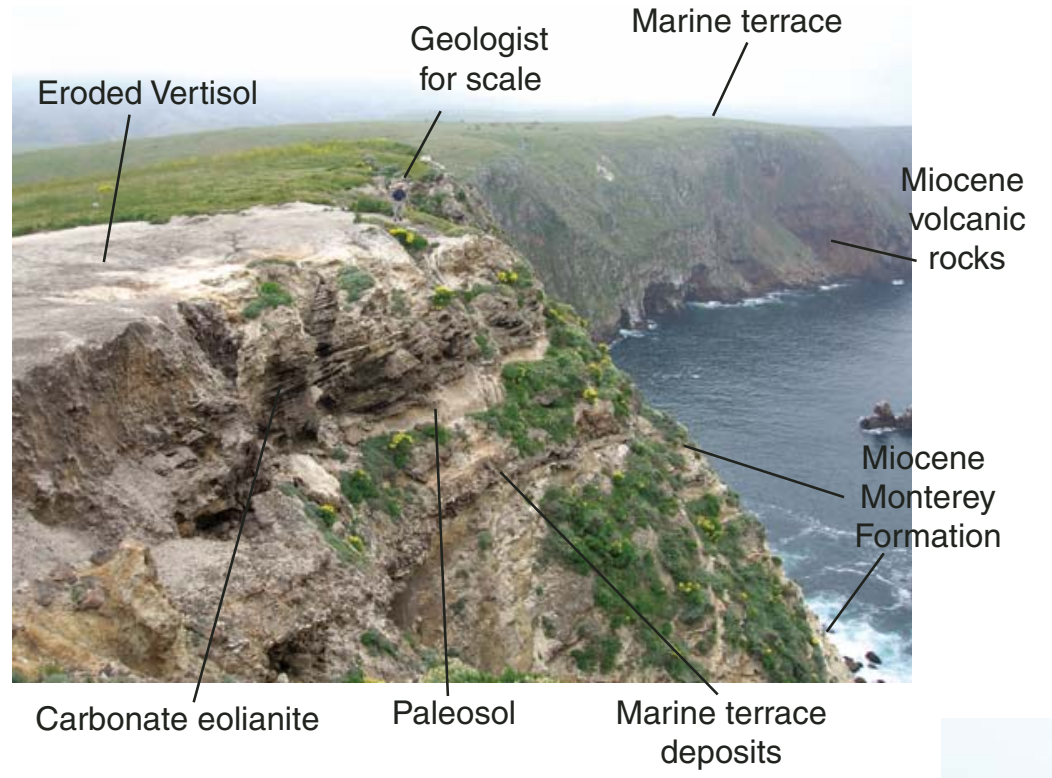

B Santa Barbara Island

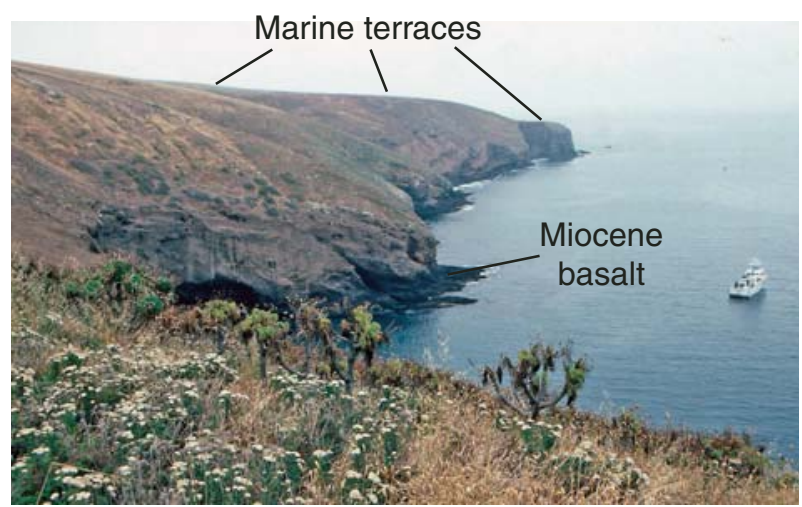

\section{East Anacapa Island}
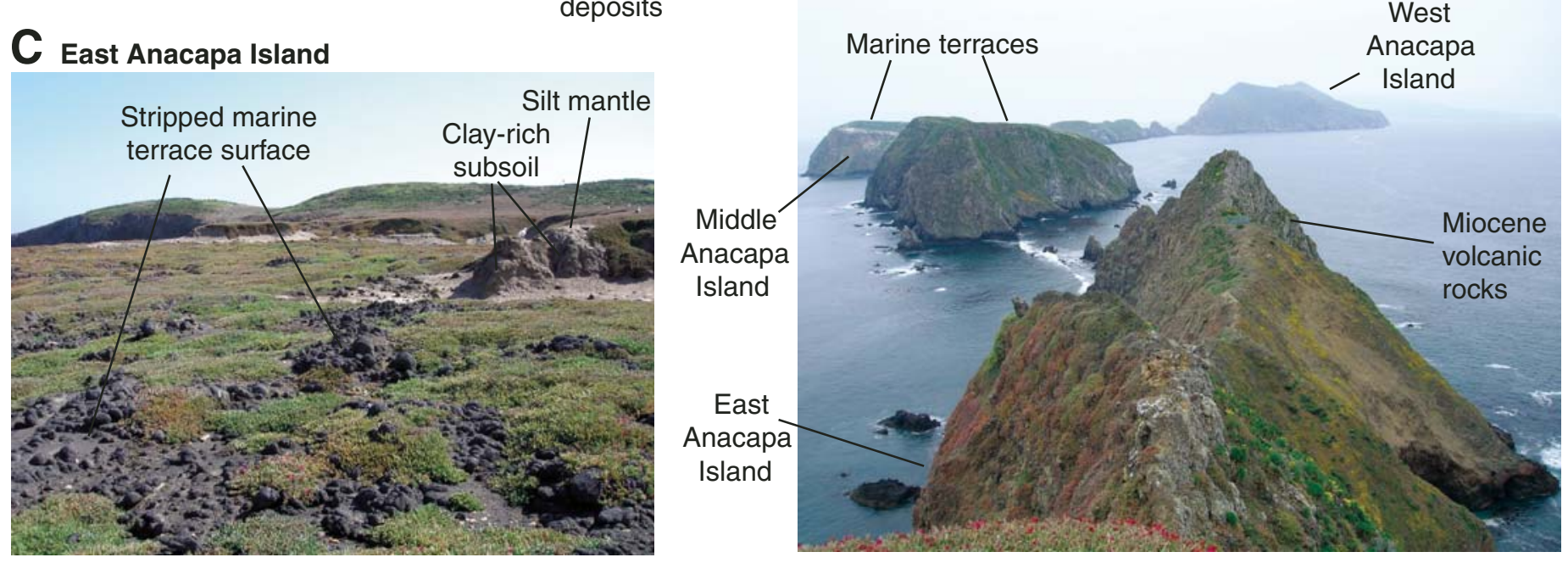

Figure 3. Geology and coastal geomorphology of Channel Islands National Park on (A) Santa Cruz Island, (B) Santa Barbara Island, (C) East Anacapa Island, and (D) all three Anacapa Islands. Photographs by the authors.

on the western side of the island, where they have received more detailed study. Pinter et al. (1998) and Scott and Pinter (2003) recognize three broad terrace levels on this island, based on elevations: T1 (low elevation), T2 (intermediate elevation), and T3 (high elevation). Pinter et al. (1998) report U-series ages on corals of ca. $120 \mathrm{ka}$ for the T1 terrace on western Santa Cruz Island and infer ages of ca. $320 \mathrm{ka}$ for T2 and ca. 400 ka for T3, based largely on an assumption of a constant uplift rate and correlation with the deep-sea, oxygen-isotope record. Terraces on eastern Santa Cruz Island have not received as much study. Weaver and Meyer (1969) identified marine terrace deposits and overlying eolianite that they called the Potato Harbor Formation, between Cavern Point and
Potato Harbor (Fig. 4). These workers considered the marine terrace facies of the Potato Harbor Formation to be of Pliocene age, based on the presence of an extinct faunal element, $\mathrm{Pec}$ ten healeyi Arnold. The same terrace surface is shown as Figure 4 in Scott and Pinter (2003), and is correlated with their T3 terrace group, considered to be ca. $400 \mathrm{ka}$. Thus, whether this terrace is Pliocene or Pleistocene is still not clear. In addition, however, Scott and Pinter (2003) mapped additional terrace remnants northwest of San Pedro Point. Our observations suggest that even higher terrace remnants exist on the interfluve between Smugglers Canyon and San Pedro Canyon. Soils are better preserved here, and our samples come from this area (Fig. 4).
Marine terraces also dominate the geomorphology of East and Middle Anacapa Islands and parts of West Anacapa Island (Fig. 3C). According to Scott and Pinter (2003) and Pinter et al. (2003), who correlated the terraces on Anacapa with those on Santa Cruz Island, the main surface on East and Middle Anacapa Islands is the T3 terrace, interpreted to be ca. $400 \mathrm{ka}$. On Middle Anacapa Island, this terrace occurs at an elevation of $\sim 76 \mathrm{~m}$ and contains an extinct faunal element (the gastropod Calicantharus fortis), also found on Santa Barbara Island (Valentine and Lipps, 1963), consistent with the ca. 400-ka age estimate of Scott and Pinter (2003). Our soil localities are all on what Scott and Pinter (2003) called the T3 terrace surface of East Anacapa Island. Our own observations 

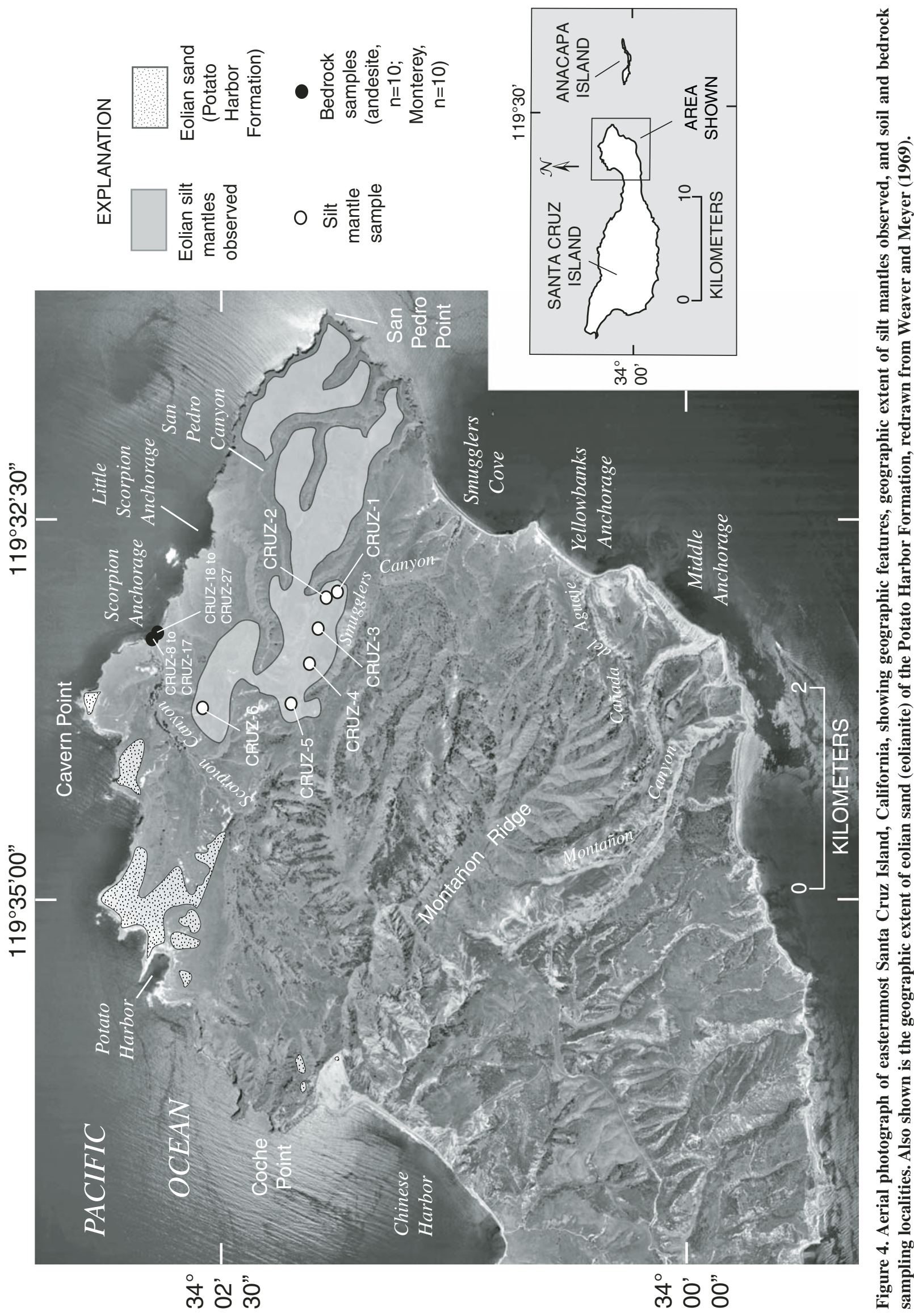
suggest that more than one terrace level is probably present on East Anacapa Island, but available exposures do not allow a clear differentiation of multiple terraces.

Like the other two islands, the geomorphology of Santa Barbara Island is dominated by a series of marine terraces (Fig. 3B). Marine terraces on this island have not been mapped, owing to poor exposures, but Lipps et al. (1968) report at least six terraces, at elevations of $\sim 1.5 \mathrm{~m}, \sim 8-9 \mathrm{~m}$, $\sim 15 \mathrm{~m}, \sim 40 \mathrm{~m}, \sim 61 \mathrm{~m}$, and $\sim 76 \mathrm{~m}$. In addition, Dibblee (2001a) mapped terrace deposits (without differentiation of individual terraces) up to elevations of $\sim 120 \mathrm{~m}$, consistent with our own observations. Our soil localities lie at elevations of $\sim 100-110 \mathrm{~m}$, and therefore are on the highest terrace remnants.

There are presently no age estimates for any of the terrace deposits on Santa Barbara Island. Nevertheless, some inferences can be made about possible ages using the faunas presented by Lipps et al. (1968). With one possible exception, the terrace at $~ 8$ - to 9-m elevation contains no extralimital northern species of mollusks; however, it does contain several extralimital southern or southward-ranging species. Based on the warm-water fossil assemblage, it is likely that this terrace dates to the peak of the last interglacial period, ca. $120 \mathrm{ka}$ (Muhs et al., 2002, 2006). If so, its shoreline-angle elevation at $\sim 8-9 \mathrm{~m}$ indicates tectonic uplift of no more than $\sim 4 \mathrm{~m}$ in $120 \mathrm{ka}$ (based on a paleo-sealevel elevation of $+5-6 \mathrm{~m}$ at $120 \mathrm{ka}$; see Muhs, 2002). This yields a very low, long-term uplift rate of $\sim 0.03 \mathrm{~m} / \mathrm{ka}$. This inference is consistent with the presence of an extinct faunal element (the gastropod Calicantharus fortis) on a higher $(\sim 40 \mathrm{~m})$ terrace (Lipps et al., 1968). On San Nicolas Island, this gastropod is found in deposits of the fifth $(\sim 114 \mathrm{~m})$ and higher terraces (Vedder and Norris, 1963), but not on any lower (younger) terraces. The fifth terrace on San Nicolas Island is older than ca. $120 \mathrm{ka}$, younger than ca. $500 \mathrm{ka}$, and could be ca. $250 \mathrm{ka}$ (Muhs et al., $2004 \mathrm{~b}$ ). Thus, we infer that the $\sim 40-\mathrm{m}$ terrace on Santa Barbara Island is at least ca. $250 \mathrm{ka}$, could be older than ca. $500 \mathrm{ka}$, and based on the possible uplift rate, could be older than 1.0 Ma. The host terrace for our soils, at 100-110 m, must, therefore, be substantially older.

\section{SOILS OF EASTERN CHANNEL ISLANDS NATIONAL PARK}

There have been very few studies of the soils on Santa Barbara, Anacapa, and Santa Cruz Islands. Johnson (1979) mapped the soils on Santa Barbara and Anacapa Islands. Because his maps have limited availability, we present them in this paper, with soil taxonomic updates

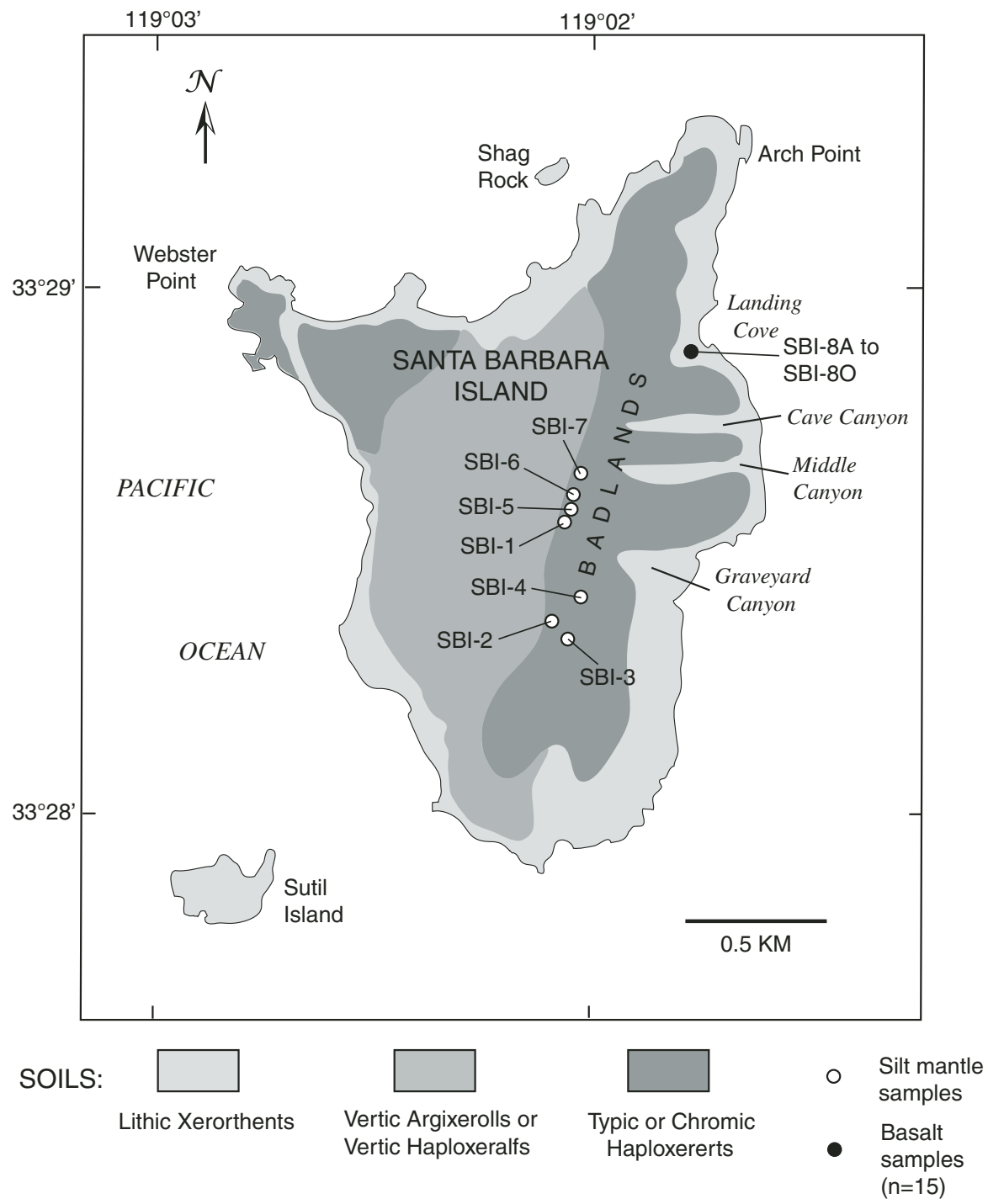

Figure 5. Soil map of Santa Barbara Island (redrawn from Johnson, 1979), showing soil sample and bedrock sample localities.

(Figs. 5 and 6). On Santa Barbara Island, thin soils on steep slopes along sea cliffs or near canyons are Lithic Xerorthents that lack B horizons. On flat-lying marine terrace deposits, soils are Typic or Chromic Haploxererts. Above the terrace levels, on gentle bedrock slopes, soils are either Vertic Argixerolls or Vertic Haploxeralfs, depending on how dark the A horizons are (Fig. 5). On East Anacapa Island, the same three groups of soils are observed, with Lithic Xerorthents on steep slopes and Typic or Chromic Haploxererts on flat-lying portions of most marine terrace remnants. In the north-central part of the island, the soils have well-developed Bt horizons and are likely Vertic Argixerolls or Vertic Haploxeralfs (Fig. 6).

Jones and Grice (1993) and Butterworth et al. (1993) mapped and described the soils on central and western Santa Cruz Island. Their map also presented the distribution of possible soil types on eastern Santa Cruz Island, using a Geographic Information System (GIS)-based model of soil-forming factors. However, the GIS-based soils map for eastern Santa Cruz Island was not field checked and is therefore preliminary. We have not mapped the soils on eastern Santa Cruz Island, but field reconnaissance permits some broad observations. On the terrace remnants above Smugglers Cove, at elevations up to $\sim 90 \mathrm{~m}$, we observed well-developed, dark (10YR 2/2, 3/1) Vertisols (Typic Haploxererts), with higher terrace remnants hosting stripped soils with reddish-brown Bt horizons. At still higher elevations (up to $\sim 240 \mathrm{~m}$ ), on relatively flat terrace remnants, soils are also Typic Haploxererts. Farther north, between Scorpion 


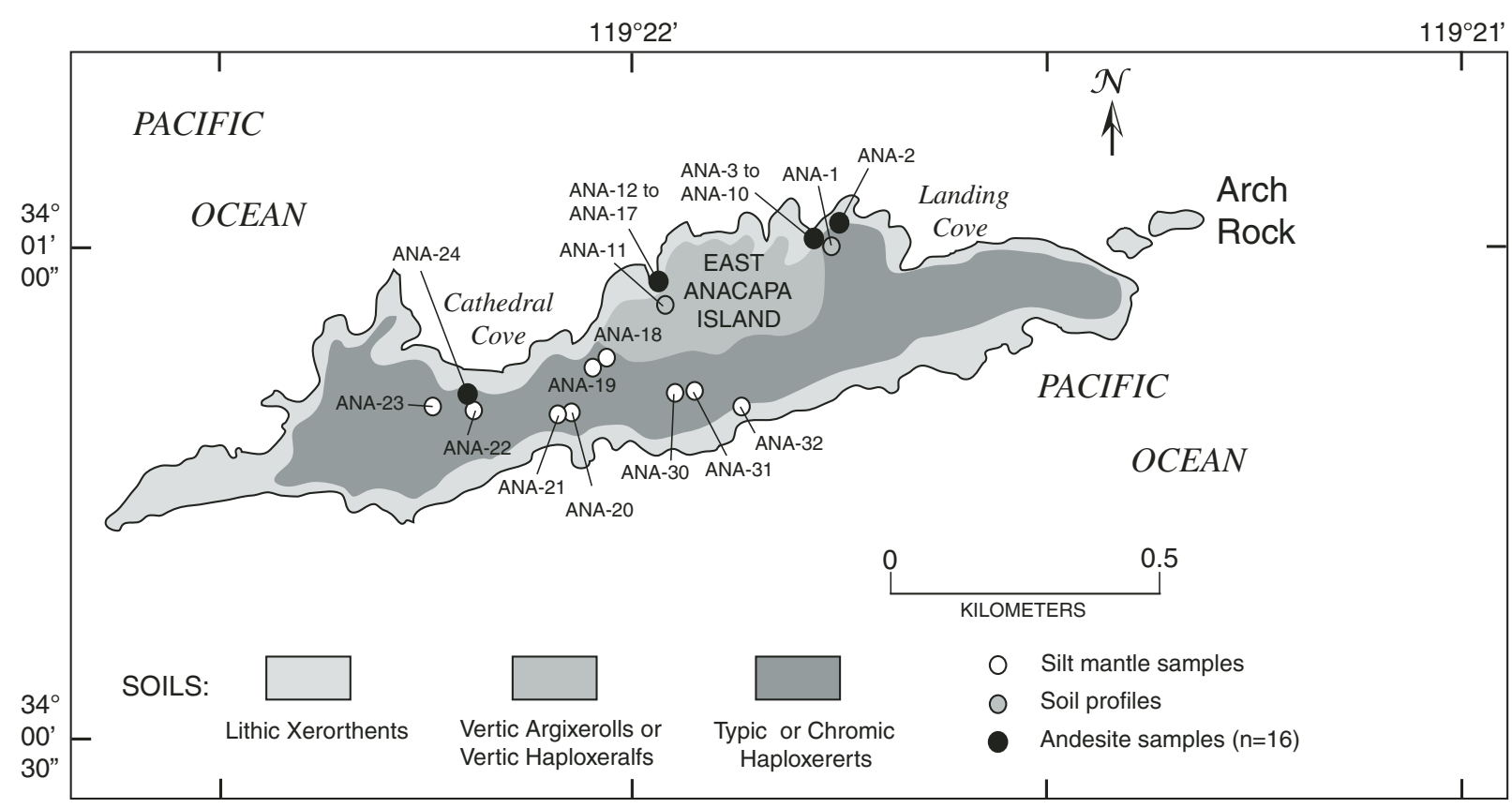

Figure 6. Soil map of East Anacapa Island (redrawn from Johnson, 1979), showing soil sample and bedrock sample localities.

Anchorage and Potato Harbor (Fig. 4), on old marine terrace remnants capped by carbonate eolianite, upland soils are also Typic Haploxererts or remnants of these soils (Fig. 3). Many soils in this area have been stripped, but in places we observed and described well-developed Vertisols as much as $100 \mathrm{~cm}$ thick.

\section{SILT MANTLES ON SOILS OF EASTERN CHANNEL ISLANDS NATIONAL PARK}

Silt mantles are present on all three of the islands studied (Fig. 7). On Santa Barbara Island, they are present in all areas in the central part of the island, except in the "Badlands" area, where historic soil stripping has been active. Where present, they are $2-5 \mathrm{~cm}$ thick, have light brownish gray (10YR 6/2) colors (all colors given here are for dry soil), and a silt loam texture. The silt mantles on Santa Barbara Island resemble those described by Muhs $(1982,1983)$ and Muhs et al. (2007b) from San Clemente Island, $\sim 70 \mathrm{~km}$ to the southeast (Figs. 1 and 7). The silt mantles have an abrupt boundary with the underlying, dark, clay-rich Vertisols on both islands. On San Clemente Island, silt mantles have similar morphology and thicknesses on terraces ranging in age from less than $100,000 \mathrm{yr}$ to greater than 1,000,000 yr (Muhs et al., 2007b).

On East Anacapa Island, silt mantles are very similar to those on Santa Barbara Island, although colors are somewhat darker and more variable. Most are dark, grayish brown (10YR
$4 / 2$ ) or grayish brown (10YR $5 / 2)$, but they range from brown (10YR 5/3) to very dark, grayish brown (10YR 3/2). On East Anacapa Island, silt mantles range from $\sim 2 \mathrm{~cm}$ thick to as much as $\sim 30 \mathrm{~cm}$ thick. The silt mantles here also contrast strongly with the clay-rich, angular blocky peds of the underlying Vertisol horizons or Bt horizons of soils that are vertic intergrades (Fig. 7). In places, we observed silt coatings on ped faces as deep as $\sim 58 \mathrm{~cm}$, where silt-mantle material has fallen into cracks during the dry season.

Unlike Santa Barbara and East Anacapa Islands, silt mantles are not ubiquitous on eastern Santa Cruz Island. They are best preserved on broad, flat interfluves between Smugglers Canyon and Scorpion Canyon (Fig. 4). They are as thick as $\sim 24 \mathrm{~cm}$, and some have platy structure and small vesicles. Colors of silt mantles on eastern Santa Cruz Island range from light, yellowish brown (10YR 6/4) to brown (10YR $5 / 3,4 / 3$ ), grayish brown (10YR 5/2), or dark, grayish brown (10YR 4/2). Where we observed them, silt mantles are underlain by dark Vertisols with clayey textures and well-developed angular blocky structure. As on Anacapa Island, silt coatings were observed on Vertisol ped faces to depths of $\sim 80 \mathrm{~cm}$ or more, where they have been eroded into cracks. Biologic ("cryptogamic") soil crusts cover silt mantles on all three islands (Fig. 7). These crusts are similar to those described by Rosentreter and Belnap (2001) for San Nicolas Island.

\section{PARTICLE-SIZE DISTRIBUTION OF CHANNEL ISLANDS SILT MANTLES}

Silt mantles on the Channel Islands have particle-size distributions that resemble finegrained eolian sediments found in other regions (Figs. 8A-8C). All silt mantles are finer grained and more poorly sorted than shelf sands from Anacapa Island (although, note that these samples were not analyzed by laser particlesize methods) or typical dune sand from desert regions (the Taklimakan Desert in China and the Kalahari Desert in Africa). Furthermore, the silt mantles have mean particle sizes and degrees of sorting that are similar to, though not identical to, loess from North America (Colorado and Illinois) and China. The particle-size distributions of silt mantles are closest to Mojave Desert dust.

On Santa Barbara Island, mean particle sizes (as calculated by the method of moments) fall between 6 phi $(\sim 16 \mu \mathrm{m})$ and 7 phi $(\sim 8 \mu \mathrm{m})$, although modes are typically around $30 \mu \mathrm{m}$ (Fig. 8C). A secondary mode in the fine-clay fraction $(\sim 0.3-0.4 \mu \mathrm{m})$ explains mean particle size that is finer than the modal particle size. Santa Barbara Island silt mantles have mean particle sizes and degrees of sorting that fall into the finer range of Mojave Desert dust samples (Fig. 8C).

Silt mantles on East Anacapa Island have a wider range of mean particle sizes (Fig. 8B). Mean values range from just under 5 phi (31 $\mu \mathrm{m})$ to somewhat less than 7 phi $(\sim 8 \mu \mathrm{m})$, 


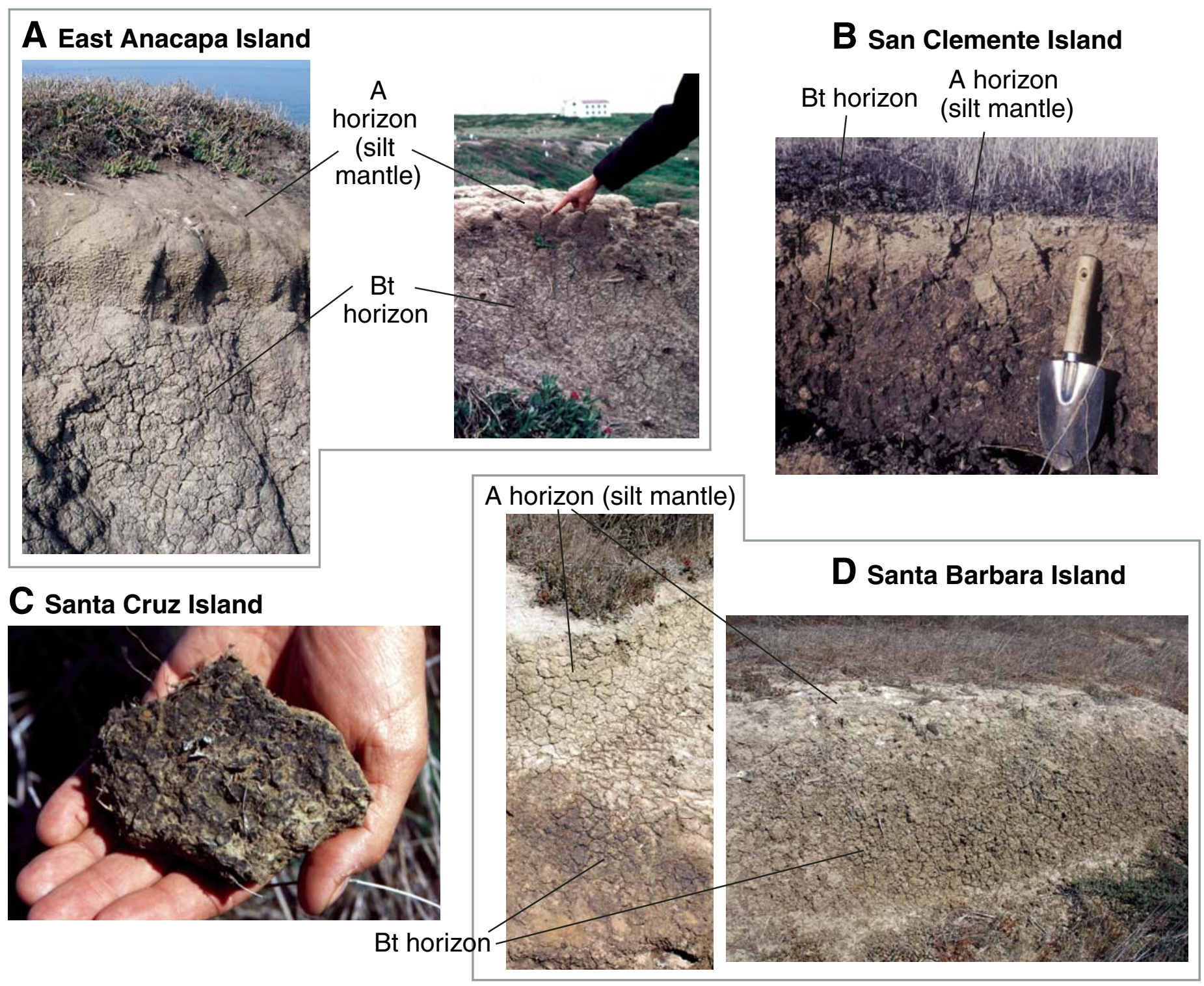

Figure 7. Soils on the California Channel Islands: (A) Vertic Haploxeralfs on East Anacapa Island, showing light-colored silt mantles overlying clay-rich Bt horizons; (B) Vertic Haploxeralf on San Clemente Island, showing light-colored silt mantle overlying darker, clay-rich Bt horizon; (C) hand specimen of silt mantle from Santa Cruz Island, showing biologic soil crust on surface of silt mantle; and (D) Vertic Haploxeralfs on Santa Barbara Island, showing light-colored silt mantle overlying clay-rich Bt horizons.

similar to the entire range of Mojave Desert dust samples. Most East Anacapa Island silt mantles have a modal particle size of $\sim 40-50$ $\mu \mathrm{m}$, but with secondary modes in the fine-sand and fine-clay fractions. All silt mantles on East Anacapa Island are more poorly sorted than Mojave Desert dust samples, and much more poorly sorted than loess from Colorado, Illinois, or China. The coarser mean size and poorer sorting of East Anacapa Island silt mantles suggest the possibility of some local eolian sand input.

Santa Cruz Island silt mantles have mean particle sizes similar to those on Santa Barbara
Island, between 6 phi $(\sim 16 \mu \mathrm{m})$ and 7 phi $(\sim 8$ $\mu \mathrm{m})$, but with a mode around $40 \mu \mathrm{m}$. Secondary modes are present in the fine-sand and fine-clay fractions. Silt mantles on Santa Cruz Island have a degree of sorting that is similar to Colorado loess and Mojave Desert dust (Fig. 8A).

\section{MINERALOGY AND MAJOR-ELEMENT GEOCHEMISTRY OF CHANNEL ISLANDS ROCKS}

Volcanic rocks from Santa Barbara Island near Landing Cove are mostly basalt, with one sample of basaltic andesite (Fig. 2). Weigand et al. (1998) reported basalt, basaltic andesite, and andesite from other localities on Santa Barbara Island. X-ray diffraction (XRD) analysis of our rock samples is consistent with the wholerock geochemistry, revealing only plagioclase (albite) and no evidence of quartz, K-feldspar, amphibole, or mica. All East Anacapa Island rocks we studied are andesites, with one basaltic andesite, similar to what has been reported by Weigand (1993) and Weigand and Savage (2002) and similar to the dominant rock type on San Clemente Island (Fig. 2). All samples analyzed by XRD have abundant plagioclase, 


\section{A Eastern Santa Cruz Island}

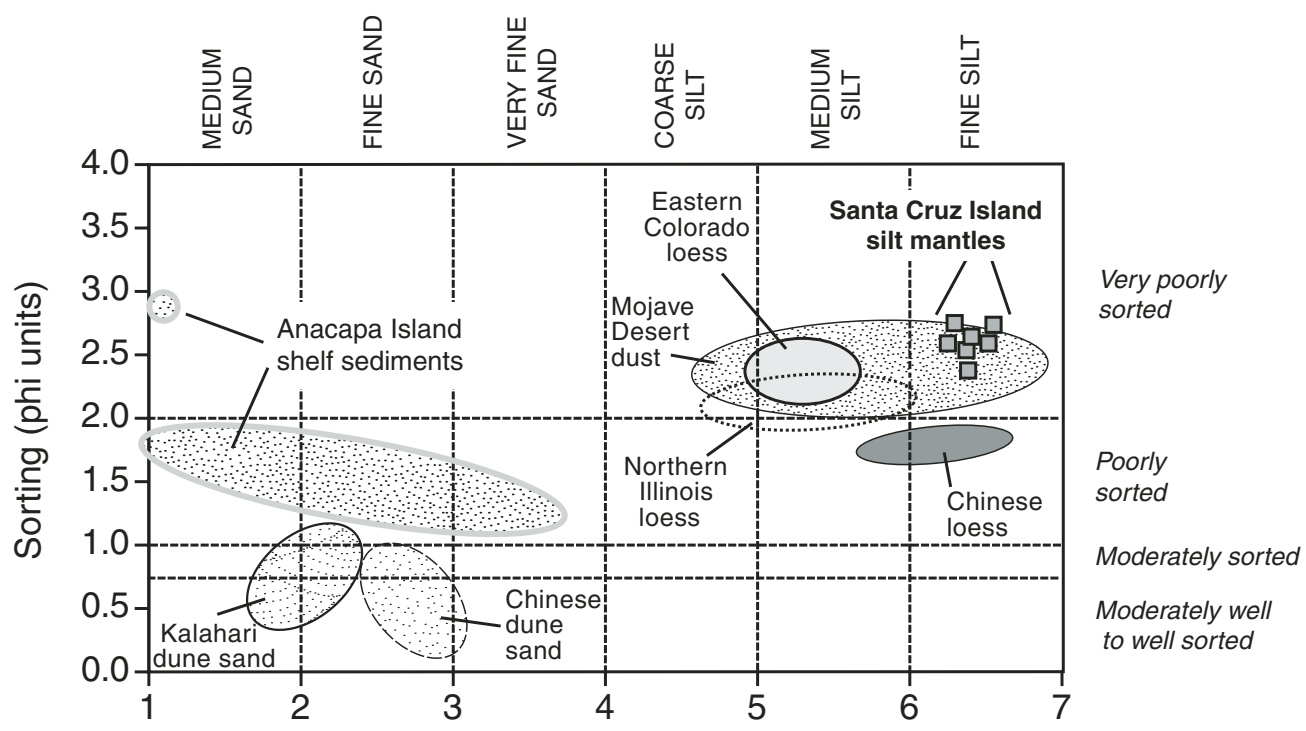

B East Anacapa Island

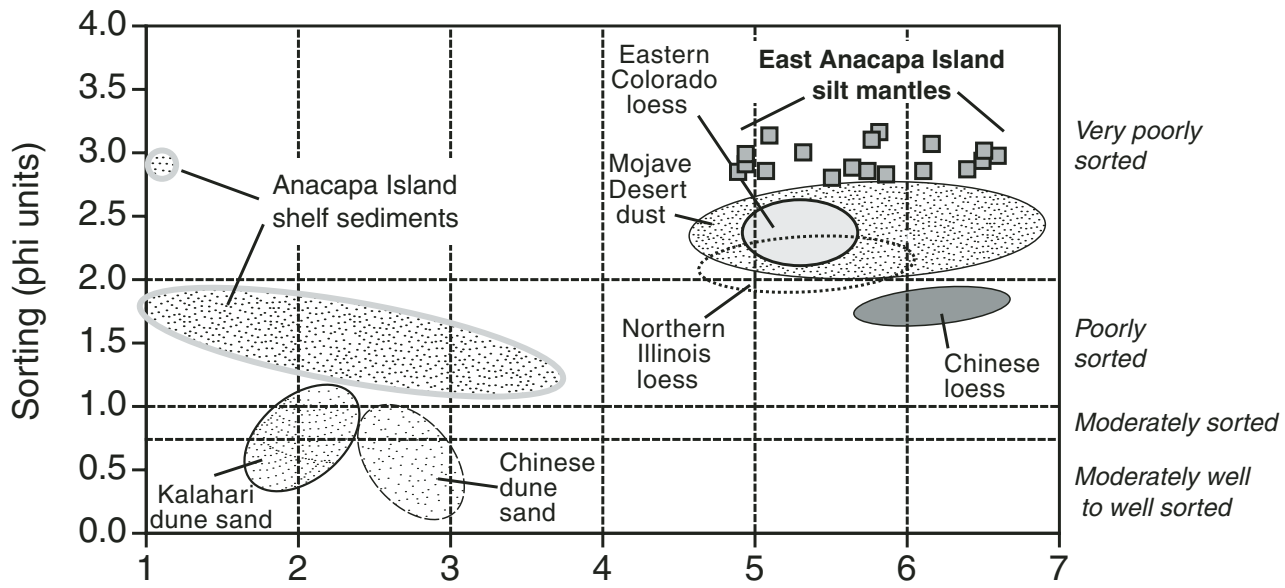

\section{Santa Barbara Island}

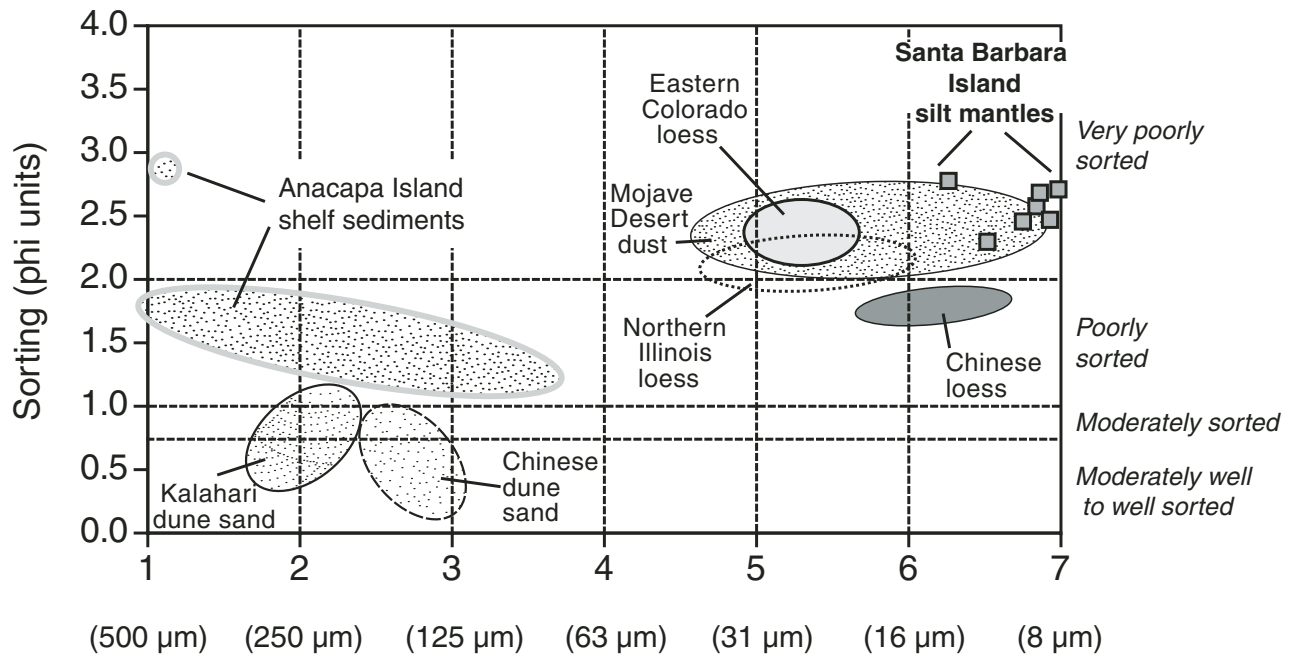

Mean particle size (phi units)
Figure 8. Plot of mean particle size and degree of sorting (standard deviation of the mean particle size) of silt-enriched mantles (squares) from (A) eastern Santa Cruz Island, (B) East Anacapa Island, and (C) Santa Barbara Island. Also shown for comparison are ranges of mean particle size and degree of sorting of eolian sediments from other areas. Eastern Colorado loess data are from Muhs and Benedict (2006); northern Illinois loess data are new, from the section at Morrison, Illinois (Muhs and Bettis, 2000; Bettis et al., 2003); Chinese loess data are from the Luochuon and Xifeng sections and are from Lu et al. (2001). Mojave Desert dust data are from Reheis (2003). Chinese dune sand data are from the Taklimakan Desert and are from Wang et al. (2002); Kalahari dune sand data are from Livingstone et al. (1999); Anacapa Island shelf sediments are from Scholl (1960). All analyses were done by laser particle-size methods, except Anacapa Island shelf sediments. 
and most have identifiable pyroxene, consistent with the major-element chemistry and similar to what was reported by Weigand (1993), based on more detailed petrography. Only one sample we studied showed a very small quartz peak; all others have no evidence of quartz. None of the East Anacapa Island rocks have identifiable mica, amphibole, or K-feldspar.

The eastern part of Santa Cruz Island has volcanic rocks (named the Santa Cruz Island Volcanics) of Miocene age, overlain in places by the Monterey Formation shale. We determined major-element geochemistry of volcanic rocks collected at Scorpion Anchorage on Santa Cruz Island (Fig. 4). These analyses show that one sample is basaltic andesite and all others are andesite. These data are in broad agreement with Weigand (1993) and Weigand and Savage (2002), who report that rock composition on Santa Cruz Island ranges from basaltic andesite to dacite. Basaltic andesite samples have plagioclase, pyroxene, opaque oxides, and glass; andesite and dacite samples also contain thin quartz veins (Weigand, 1993). We are not aware of any detailed mineralogical studies of the Monterey Formation on Santa Cruz Island, although Weaver and Meyer (1969) report that it is siliceous shale with abundant chert and bentonite (smectite).

\section{MINERALOGY AND TRACE-ELEMENT GEOCHEMISTRY OF SILT MANTLES ON THE CHANNEL ISLANDS}

\section{Mineralogy}

We determined the mineralogy of selected silt fraction $(53-2 \mu \mathrm{m})$ samples to compare with the local island bedrock. In this paper, we use Santa Barbara Island and East Anacapa Island as examples. On Santa Barbara Island, the silt $(53-2 \mu \mathrm{m})$ fractions of all silt mantles contain quartz, plagioclase, and K-feldspar. All but two samples also contain amphibole, and one Santa Barbara Island sample also contains mica. On East Anacapa Island, the silt (53-2 $\mu \mathrm{m})$ fractions of all silt mantle samples analyzed have quartz, plagioclase, K-feldspar, and, with one exception, amphibole. In addition, two samples also contain mica. The mineralogical compositions of these silts contrast strongly with the local bedrock of both islands, since quartz, K-feldspar, amphibole, and mica were not detected in bedrock. The only possible local sources of quartz, K-feldspar, amphibole, and mica are from the very small outcrops of the San Onofre Breccia, previously unreported, but observed by us in the western part of Cathedral Cove (Fig. 6). However, these outcrops are of such limited extent that they cannot even be mapped at 1:24,000. It is difficult to imagine, therefore, how they could be the main source for minerals in soil-surface horizons over the entire island. We conclude, therefore, that these minerals must have had origins external to the islands, because none of them is likely to have formed pedogenically.

The mineralogy of the clay $(<2 \mu \mathrm{m})$ fraction of the silt mantles also shows differences between the silt mantles and both the local bedrock and underlying soil horizons. We conducted detailed clay mineralogical analyses of two soil profiles, one on East Anacapa Island and one on Santa Cruz Island. The East Anacapa Island profile has a thin $(\sim 2-\mathrm{cm})$ silt mantle that forms the A horizon, with a well-developed Bt horizon more than $60 \mathrm{~cm}$ thick below it. X-ray diffractometry shows that clays in the silt mantle are mica, kaolinite, and possibly quartz. In contrast, the underlying Bt1 and Bt2 horizons have all these minerals, but also contain abundant smectite (Fig. 9). The absence of smectite in the silt mantle suggests a different origin for this horizon compared to the lower horizons. In the horizons below the silt mantle, the height and sharpness of the smectite peaks increase with depth. Interestingly, mica and quartz (?) are present at all depths, suggesting that input of minerals external to the island may not be limited to the silt mantles. On Santa Cruz Island, the silt mantle is $\sim 12 \mathrm{~cm}$ thick, and clays in it are kaolinite, minor smectite and mica, and possibly quartz. The profile as a whole is a Vertisol, and abundant smectite and kaolinite (but no mica) characterize the lowest depths (Fig. 10).

\section{Trace-Element Geochemistry: Sc-Th-La and Ta-Nd-Cr}

Studies by Taylor and McLennan (1985) have shown that Sc-Th-La ternary diagrams show distinct differences between oceanic crust and upper-continental crust. Because of enrichments of Sc in oceanic crust and enrichments of Th and La in upper-continental crust, basalts will plot in the lower right (near the Sc apex) portion of a Sc-Th-La ternary diagram, whereas upper-crustal rocks will plot in the upper center. Ternary diagrams for Sc-Th-La have been used for a variety of provenance studies, including the origin of graywackes in Australia (Bhatia and Crook, 1986), the provenance of Pacific Ocean pelagic sediments (Olivarez et al., 1991), and the original tectonic setting of siliciclastic rocks in Tibet (Zhang, 2004).

Bedrock on all three islands has Sc-Th-La fields distinct from upper-continental crust. A ternary diagram of Sc-Th-La for basalt from Santa Barbara Island (Fig. 11A) compared to
Mojave Desert dust shows precisely the kind of discrimination between oceanic crust and upper-continental crust described by Taylor and McLennan (1985). Santa Barbara Island basalt plots in the lower-right portion of the diagram, showing a relative enrichment in Sc, whereas Mojave Desert dust, though variable, is centered on the average composition of upper continental crust. Andesites on Santa Cruz Island and East Anacapa Island (Figs. 11B and 11C) show less Sc enrichment than basalt, which is expected. Nevertheless, the fields defined by these volcanic rocks are distinct from Mojave Desert dust. Monterey Formation shale from Santa Cruz Island defines a field closer to, but distinct from, Mojave Desert dust.

The silt fractions of the silt mantles on all three islands have very similar Sc-Th-La compositions, despite differences in local bedrock compositions. Furthermore, none of the islands has a silt composition that falls on the Sc-Th-La fields defined by the local bedrock. In contrast, silt fractions of all three islands fall within the Sc-Th-La field defined by Mojave Desert dust.

The clay fractions of silt mantles for all islands also do not fall on the Sc-Th-La fields defined by local bedrock, although the clays from East Anacapa Island are close to the bedrock field. On Santa Cruz and Santa Barbara Islands, however, clays fall between the fields defined by local bedrock and Mojave Desert dust. The clay fractions from silt mantles on Santa Cruz Island are close to, but do not fall within, the field defined by Monterey shale, suggesting possible derivation of the clays from Monterey shale. However, such an interpretation would also require a mix with some high-Th, low-La source, and none of the other parent materials has this composition. The positions of the clays from Santa Cruz and Santa Barbara Islands do, however, permit an interpretation of a mix of local bedrock and Mojave Desert dust.

The relative abundances of $\mathrm{Ta}-\mathrm{Nd}-\mathrm{Cr}$, plotted in ternary form, provide an assessment of possible parent materials complementary to ScTh-La. Oceanic-crustal rocks are enriched in $\mathrm{Cr}$ and relatively depleted in $\mathrm{Ta}$ and $\mathrm{Nd}$, whereas upper-continental crustal rocks are depleted in $\mathrm{Cr}$ and relatively enriched in $\mathrm{Ta}$ and $\mathrm{Nd}$. As with Sc-Th-La, the basalt on Santa Barbara Island, when compared to Mojave Desert dust, shows these differences very clearly (Fig. 12). The silt fractions of silt mantles from all three islands have similar abundances of Ta-Nd-Cr, as they do with Sc-Th-La. Furthermore, none of the silt-fraction fields overlaps the field defined by local volcanic bedrock, although (as was the case with Sc-Th-La), the silt fraction field for East Anacapa Island plots close to the andesite 


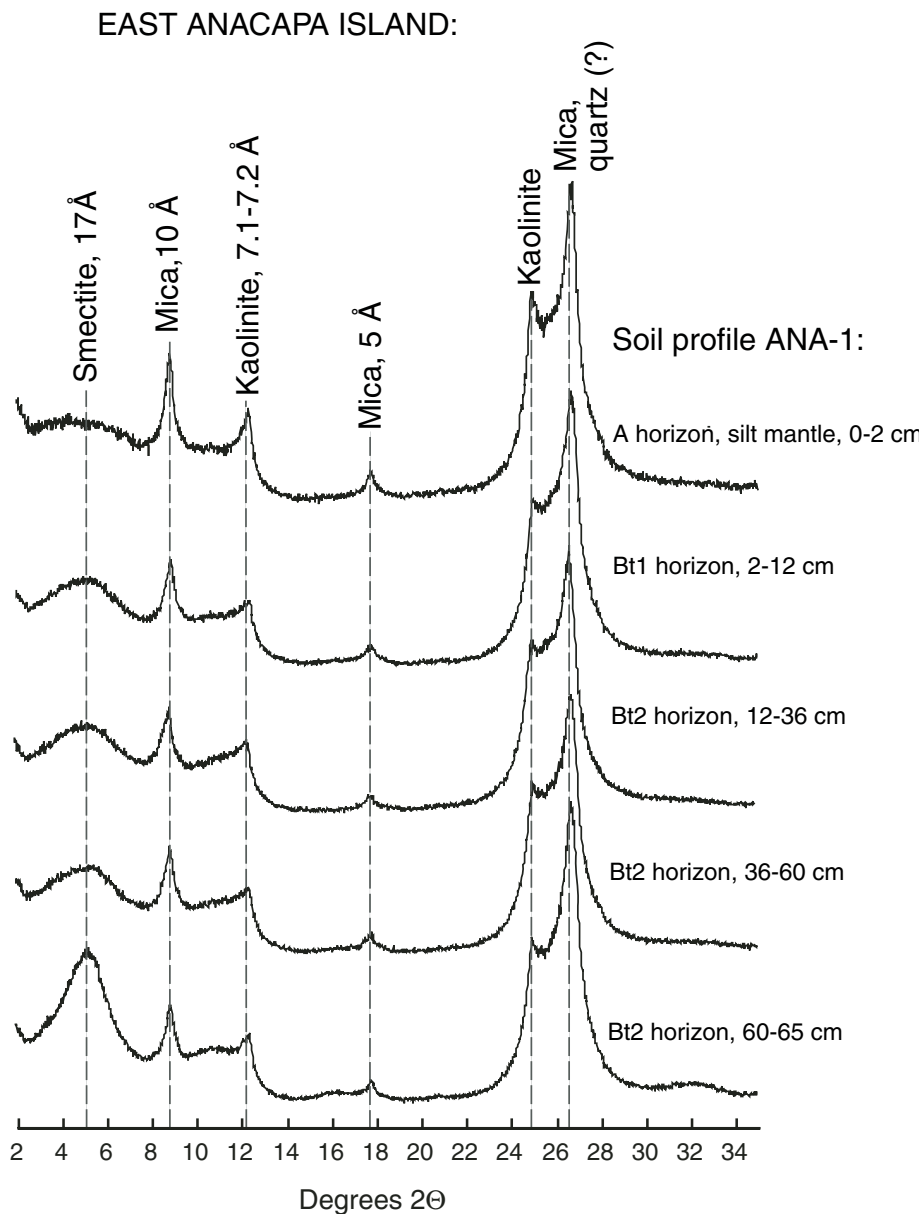

Figure 9. X-ray diffractograms (glycolated, Mg-saturated) of the clay fractions of a Vertic Haploxeralf on East Anacapa Island, showing contrast in mineralogy between the silt-rich, A horizon and underlying, clay-rich, Bt horizons.

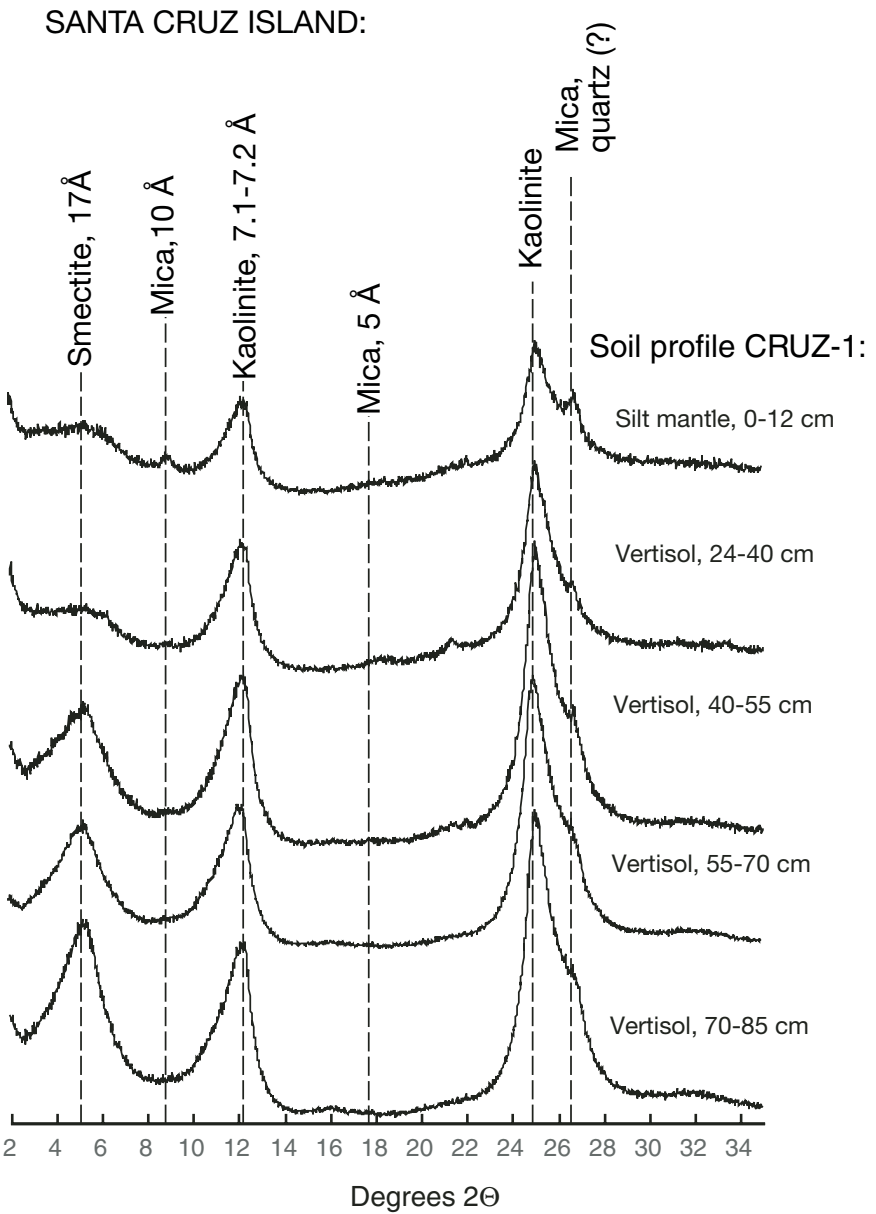

Figure 10. X-ray diffractograms (glycolated, Mg-saturated) of the clay fractions of a Vertisol on Santa Cruz Island, showing contrast in mineralogy between the silt-rich, A horizon and underlying, clay-rich, vertic horizons.
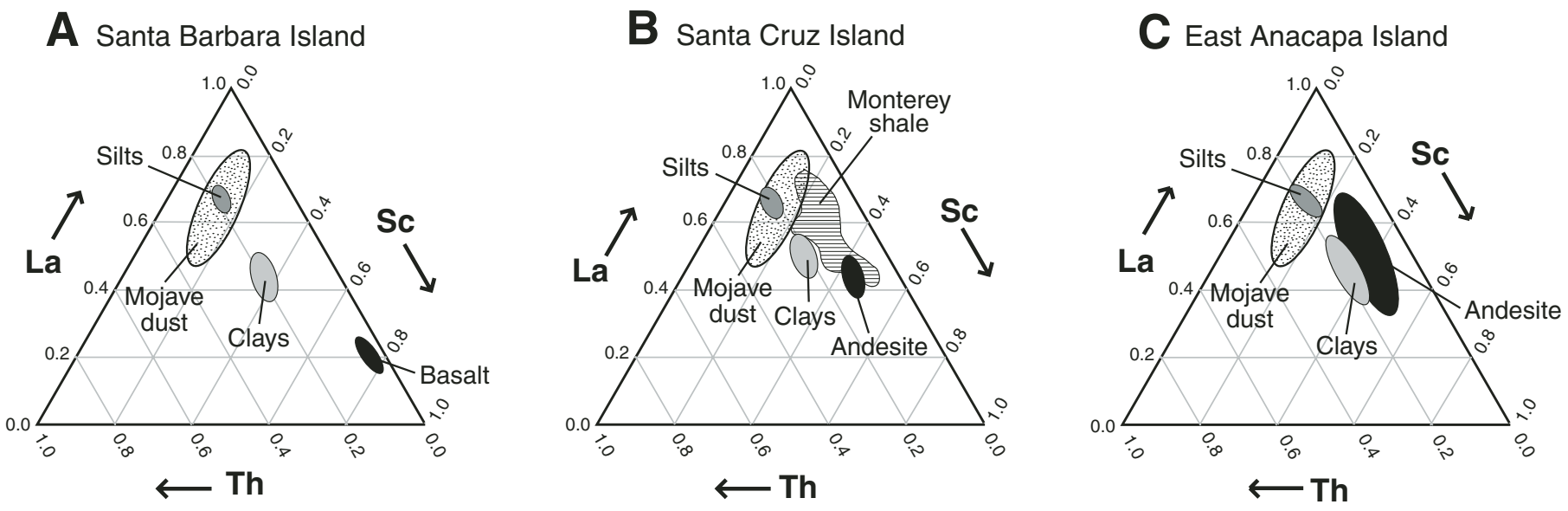

Figure 11. Ternary diagrams showing relative proportions of immobile elements Sc, Th, and La in silt fractions (53-2 $\mu \mathrm{m})$ and clay fractions $(<2 \mu \mathrm{m})$, of silt mantles on (A) Santa Barbara Island, (B) Santa Cruz Island, and (C) East Anacapa Island. Also shown is the range in values for these elements in local bedrock, consisting of andesite and shale (Santa Cruz Island), basalt (Santa Barbara Island), and andesite (East Anacapa Island). Field defined by Mojave Desert dust collected in traps is from data in Reheis (2003) and Reheis et al. (2002). 
field. The clay fractions of the silt mantles of all three islands are also similar in Ta-Nd-Cr. However, in contrast to the Sc-Th-La plots, the clay fractions of Santa Cruz and Santa Barbara Islands fall on the Ta-Nd-Cr field defined by Mojave Desert dust. The clay fractions of both of these islands have a position that could be interpreted as a mix of local bedrock and Mojave Desert dust, but a derivation solely, or at least mostly, from Mojave Desert dust could also be permitted. On East Anacapa Island, the clays of the silt mantles overlap the local bedrock, but also overlap part of the Ta-Nd-Cr field defined by Mojave Desert dust.

\section{Trace-Element Geochemistry: Rare-Earth Elements (REE)}

Rare-earth elements provide very sensitive indicators of sediment provenance (Taylor and McLennan, 1985, 1995; McLennan, 1989). REE concentrations are typically normalized to chondritic meteorite compositions, and we have followed this protocol. In the discussions of REE patterns that follow, the terms "enriched" and "depleted" are used in descriptions and interpretations. Because all samples analyzed have higher concentrations of REE compared to chondrite, "enriched" and "depleted" refer to relative abundances of different parts of the REE suite compared to other parts, e.g., light REE compared to heavy REE. Oceanic-crustal rocks (basalt) or sediments derived from such rocks have, overall, very low REE concentrations, a relatively "flat" curve (i.e., similar concentrations of light REE and heavy REE), and no Eu anomaly (i.e., Eu concentrations similar to Sm and $\mathrm{Gd})$. In contrast, upper-continental crustal rocks such as granite, or sediments derived from such rocks, have enriched light REE, a negative Eu anomaly, and depleted heavy REE. Mojave Desert dust shows typical, upper-crustal-rock REE patterns (Reheis et al., 2002).

The REE compositions of volcanic rocks with varying $\mathrm{SiO}_{2}$ content on the Channel Islands illustrate the concepts above very clearly. Basalts on Santa Barbara Island show a typical oceanic-crust type of signature, with low REE concentrations, a "flat" curve overall, and no Eu anomaly (Fig. 13). Andesites on East Anacapa Island show higher concentrations overall, somewhat enriched light REE, a negative Eu anomaly, and somewhat depleted (relative to the light REE) heavy REE. Although most of the rocks on San Clemente Island are andesite (Olmsted, 1958), small amounts of rhyolite are also present, and these rocks show a REE pattern typical of the upper crust. Rhyolites on San Clemente Island have high REE concentrations overall, enriched light REE, a strongly negative Eu anomaly, and depleted heavy REE. Andesites on Santa Cruz Island show REE patterns similar to those of andesites on East Anacapa Island, but Monterey shale on this island shows complex patterns (Fig. 14). Overall, Monterey shale has relatively low REE concentrations, only slightly enriched light REE, but strongly negative Eu anomalies. A few samples also have negative $\mathrm{Ce}$ anomalies.

Both the silt and clay fractions of the silt mantles in Channel Islands National Park display very typical upper-crustal REE compositions (Fig. 15). Both size fractions from all three islands have high overall REE concentrations (relative to chondrite), enriched light REE, negative $\mathrm{Eu}$ anomalies, and slightly depleted heavy
REE. Thus, both the silt and clay fractions of the silt mantles have patterns much like Mojave Desert dust but differ from local island andesites and basalts.

In using REE for soil or sediment provenance studies, it is helpful to reduce the data to certain key-element ratios (chondrite normalized) that give a quantitative measure of parts of the REE suite. The sign and degree of any $\mathrm{Eu}$ anomaly can be quantified by the $\mathrm{Eu} / \mathrm{Eu}^{*}$ value, where $\mathrm{Eu}$ is the chondrite-normalized $\mathrm{Eu}$ concentration $\left(\mathrm{Eu}_{\mathrm{N}}\right)$, and $\mathrm{Eu}^{*}$ is $\left(\mathrm{Sm}_{\mathrm{N}} \times\right.$ $\mathrm{Gd}_{\mathrm{N}}{ }^{0.5}$. Values less than 1.0 indicate negative Eu anomalies; values greater than 1.0 indicate positive Eu anomalies. Loess from China, for example, has $\mathrm{Eu} / \mathrm{Eu}^{*}$ values that range from 0.61 to 0.66 (Jahn et al. 2001), indicating negative Eu anomalies, typical of average upper continental crust. Another measure of REE composition reflects abundances of light and heavy REE. $\mathrm{La}_{N} / \mathrm{Yb}_{\mathrm{N}}$ is a measure of the overall enrichment of light REE, where high values reflect significant light REE enrichment.

Local island-volcanic bedrock and Mojave Desert dust are easily distinguished from one another using $\mathrm{Eu} / \mathrm{Eu}^{*}$ versus $\mathrm{La}_{\mathrm{N}} / \mathrm{Yb}_{\mathrm{N}}$ plots (Fig. 16). Mojave Desert dust has much higher $\mathrm{La}_{\mathrm{N}} / \mathrm{Yb}_{\mathrm{N}}$ than basalt or andesite and generally lower $\mathrm{Eu} / \mathrm{Eu}^{*}$. On Santa Cruz Island, Monterey Formation shale has lower $\mathrm{La}_{\mathrm{N}} / \mathrm{Yb}_{\mathrm{N}}$ and mostly lower $\mathrm{Eu} / \mathrm{Eu}^{*}$ than Mojave Desert dust. The clay fractions of silt mantles on all three islands fall mostly within the field defined by Mojave Desert dust. The silt fractions of silt mantles fall mostly between the fields defined by Mojave Desert dust and local volcanic bedrock, with the exception of East Anacapa Island, where some silts fall within the andesite field.
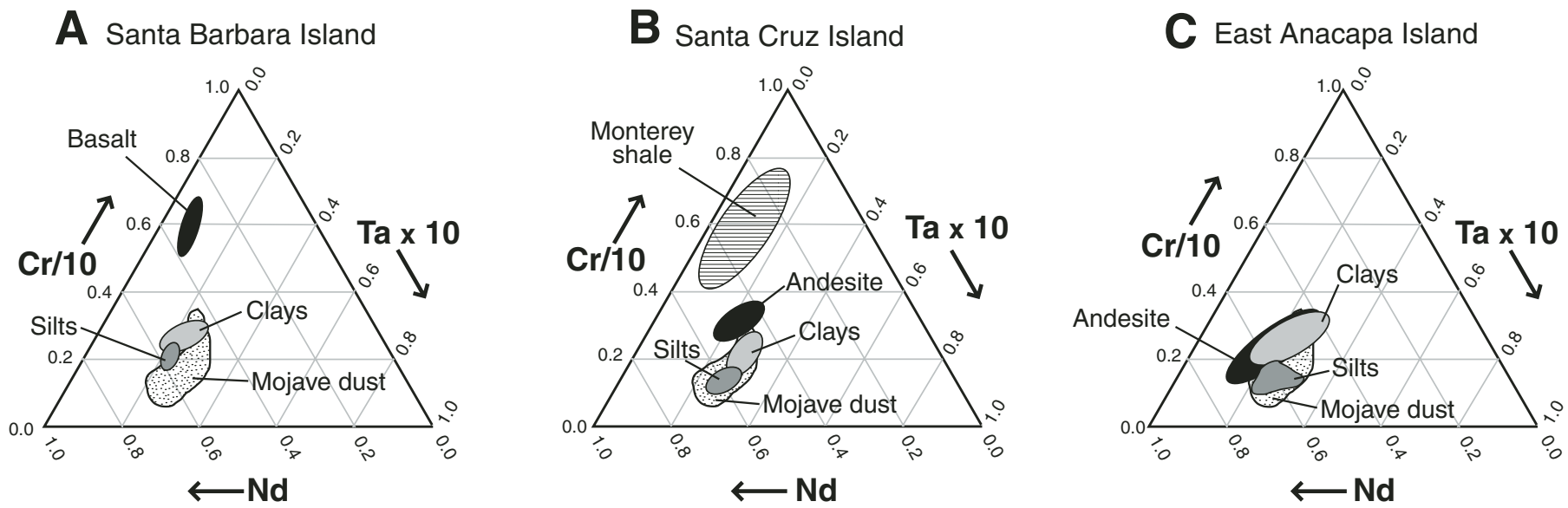

Figure 12. Ternary diagrams showing relative proportions of immobile elements $\mathrm{Ta}(\times 10)$, $\mathrm{Nd}$, and $\mathrm{Cr}(/ \mathbf{1 0})$ in silt fractions $(53-2 \mu \mathrm{m})$ and clay fractions ( $<2 \mu \mathrm{m})$ of silt mantles on (A) Santa Barbara Island, (B) Santa Cruz Island, and (C) East Anacapa Island. Also shown is the range in values for these elements in local bedrock, consisting of andesite and shale (Santa Cruz Island), basalt (Santa Barbara Island), and andesite (East Anacapa Island). Field defined by Mojave Desert dust collected in traps is from data in Reheis (2003) and Reheis et al. (2002). 


\section{DISCUSSION}

Field and Particle-Size Evidence for an External, Eolian Origin for Silt Mantles on Channel Islands National Park

The presence of silt-loam A horizons on Vertisols or soils intergrading to Vertisols is unusual. Vertisols are common in the western United States, and the U.S. Natural Resources Conservation Service (NRCS) recognizes and maps 86 official soil series (local mapping units) that belong to this order in California alone (Soil Survey Staff, 2006). Almost all of these soil series, with the exception of those established on Santa Cruz Island itself (or nearby San Clemente Island), have surface horizons with textures that fall into the "clay" or "silty clay" categories, not silt loam, which is the dominant texture of surface horizons of soils in Channel Islands National Park. Furthermore, virtually all of the Vertisols on mainland California have surface horizons with well-developed, angular blocky, subangular blocky, granular, or, less commonly, prismatic structure. Thus, massive or platy, light-colored, silt-rich surface horizons are not characteristic of Vertisols in California. We interpret this to mean that the silt mantles have a geologic, rather than pedogenic origin.

The particle-size data presented in this paper also support an external origin for the silt mantles. Although cemented dune sands are present on the Channel Islands (Fig. 3), the mean particle size of the silt mantles is distinctly different from dune sand (Fig. 8). In contrast, the silt mantles have mean particle sizes that are very similar to North American loess, Chinese loess, and Mojave Desert dust.

\section{Mineralogical Evidence for an External Origin for Silt Mantles}

Mineralogical data from both the silt and clay fractions of the silt mantles support the idea that these features have an external origin. Santa Barbara Island and East Anacapa Island are composed dominantly of basalt or andesite bedrock, yet the silt fractions of the mantles on these islands contain quartz, K-feldspar, and amphibole. Although clasts in the San Onofre Breccia contain these minerals, the extent of this unit is extremely limited, compared to the volcanic rocks. In the clay fractions of silt mantles on East Anacapa Island (and to a lesser extent on Santa Cruz Island), mica is present, which is not present in the volcanic bedrock and is unlikely to have formed pedogenically (Fanning and Keramidas, 1977). Furthermore, mica is present at all depths in soils on East Anacapa Island, suggesting that external supply of clay
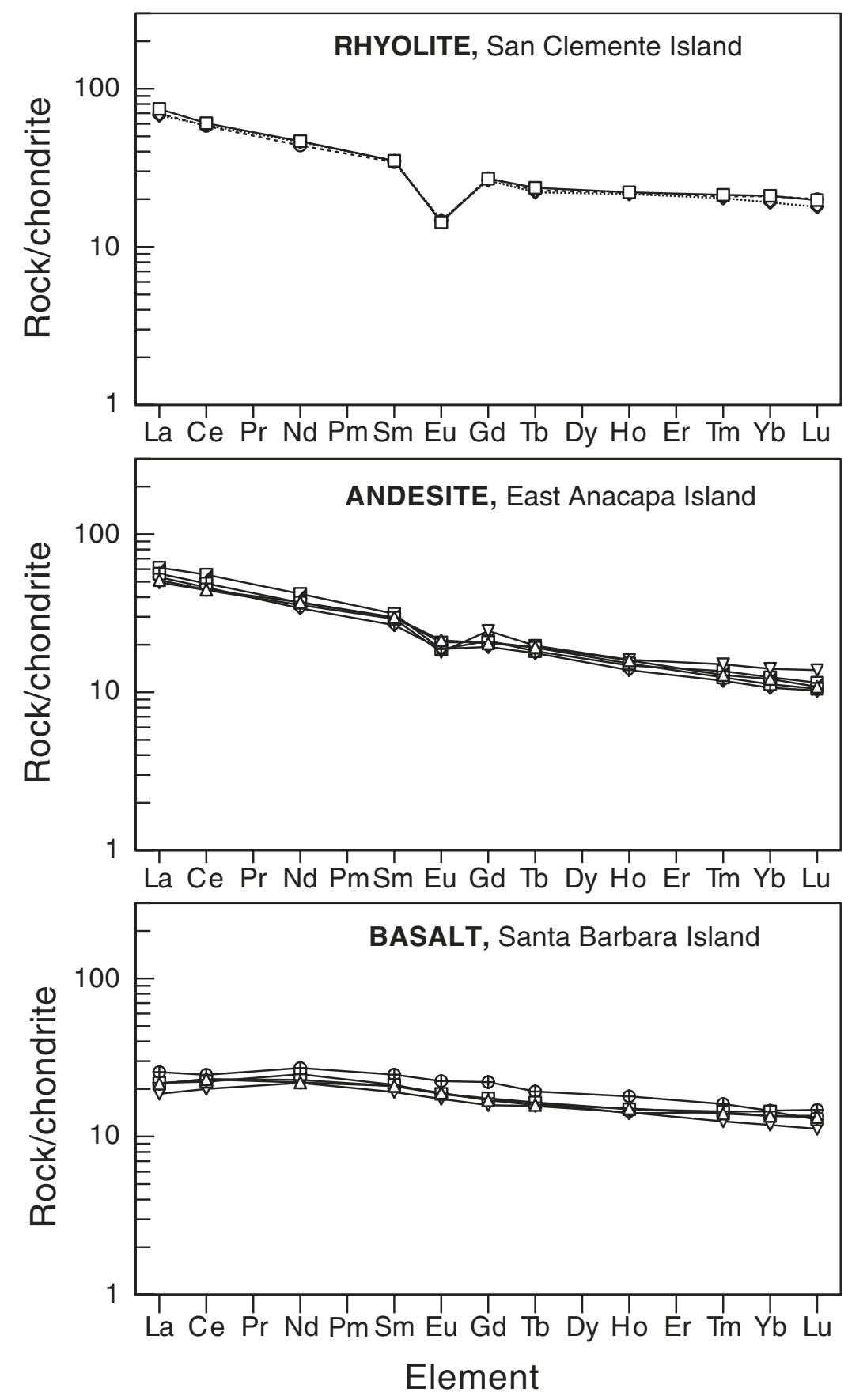

Figure 13. Chondrite-normalized, rare-earth element (REE) plots of volcanic rocks on the Channel Islands, showing decreasing light REE enrichment and decreasing negative Eu anomaly with increasingly mafic rock types (rhyolite to andesite to basalt).

minerals may have been an ongoing process for much of the period of soil formation.

Mojave Desert dust has both silt and clay mineralogy very similar to the silt mantles. The silt fractions of Mojave Desert dust have abundant quartz, followed by plagioclase and K-feldspar, with smaller amounts of mica and chlorite (Reheis and Kihl, 1995). The clay fractions of Mojave Desert dust are dominated by mica, followed by quartz, kaolinite, and smectite, with smaller amounts of chlorite and mixed-layer minerals. The mineralogy is very similar to that of the silt mantles on all three of the Channel Islands, supporting not only an external origin, but also one specifically from the Mojave Desert. 

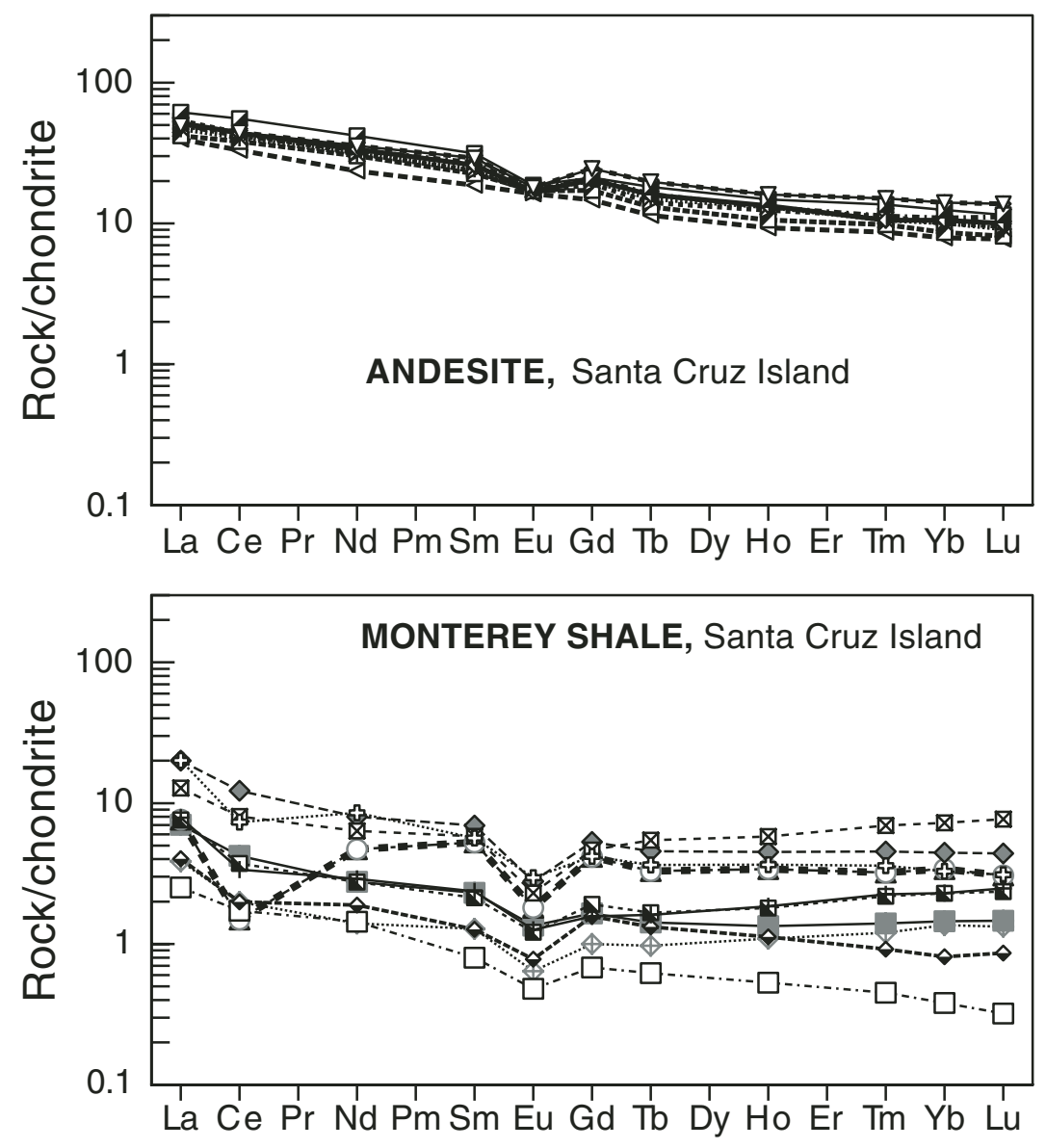

Figure 14. Chondrite-normalized, rare-earth element (REE) plots of highly contrasting rock types (andesite and shale) on eastern Santa Cruz Island.

\section{Geochemical Evidence for an External Origin for Silt Mantles}

All three geochemical indexes used here indicate that the silt fractions of the silt mantles have origins external to the islands. The silts on all three islands resemble one another, geochemically, and do not have any compositional overlap with local bedrock on Sc-Th-La or Ta-Nd-Cr plots. On REE plots $\left(\mathrm{Eu} / \mathrm{Eu}^{*}\right.$ versus $\left.\mathrm{La}_{\mathrm{N}} / \mathrm{Yb}_{\mathrm{N}}\right)$, silts overlap island bedrock only slightly on East Anacapa Island. In contrast, silts fall within the fields defined by Mojave Desert dust for Sc-Th$\mathrm{La}$ and Ta-Nd-Cr, and close to the Mojave Desert dust field for $\mathrm{Eu} / \mathrm{Eu}^{*}$ versus $\mathrm{La}_{\mathrm{N}} / \mathrm{Yb}_{\mathrm{N}}$. This does not require that Mojave Desert dust is necessarily the only source or even the main source of the silts, but that the silts are almost certainly derived from sediments of an upper-continental-crustal origin, with a composition similar to that of Mojave Desert dust.

The origin of the clay fractions of the silt mantles is not as clear as that of the silt fractions. On all three islands, clays fall between the fields defined by volcanic bedrock and Mojave Desert dust on Sc-Th-La and Ta-Nd-Cr plots, although they fall within the field defined by Mojave Desert dust on $\mathrm{Eu} / \mathrm{Eu}^{*}$ versus $\mathrm{La}_{\mathrm{N}} /$ $\mathrm{Yb}_{\mathrm{N}}$ plots. We interpret these data to indicate that the clay fractions of the silt mantles may have a complex origin. Part of the clay fraction may be derived from in situ weathering of local volcanic bedrock minerals and part of the clay fraction may be from an external source. The abundance of clay-sized mica in silt mantles on East Anacapa Island, and to a lesser extent on Santa Cruz Island, supports this interpretation, since mica is not present in the bedrock and is not likely to have formed pedogenically. On the other hand, smectite and kaolinite could be either detrital or derived from chemical weathering of volcanic bedrock.

\section{Westerly Winds and an Asian Source of Dust}

It is well documented that Asian (Chinese and Mongolian) dust can travel great distances across the Pacific Ocean, and there is a long-term record of this transport in deep-sea sediments (Rea, 1994). There is also little question that Asian dust provides regular inputs to soils of the Marianas Islands (Birkeland, 1999) and Hawaii (Rex et al., 1969; Jackson et al., 1971; Chadwick et al., 1999). Finally, there is direct observation of Asian dust traveling as far east as the Pacific Coast of North America (Husar et al., 2001), such as the dust event of April, 1998. Indeed, this latter event was observed on nearby San Nicolas Island (Tratt et al., 2001). The composition of Chinese loess is similar to that of silt mantles on the California Channel Islands in that it has REE abundances $\left(\mathrm{Eu} / \mathrm{Eu}^{*}, \mathrm{La}_{\mathrm{N}} / \mathrm{Yb}_{\mathrm{N}}, \mathrm{Gd}_{\mathrm{N}} / \mathrm{Yb}_{\mathrm{N}}\right)$ that are typical of the upper-continental crust. Nevertheless, delivery of Asian dust to North America is likely to occur only infrequently. Furthermore, the mean particle diameters during the April, 1998 event are reported to be $\sim 2 \mu \mathrm{m}$ to $\sim 4 \mu \mathrm{m}$, a particle size to be expected, given the distance of eolian transport (Husar et al., 2001; Tratt et al., 2001). However, mean particle sizes of Channel Islands silt mantles are much coarser, suggesting a source that is not as distant as Asia. Therefore, while we cannot exclude an Asian origin for the silt mantles on the Channel Islands, we consider this to be a less likely source.

\section{Northwesterly Winds and a California Mainland Source of Dust}

During most of the year, the dominant winds in coastal southern California are from the northwest or west. Because of the east-west-trending aspect of mainland California to the north of Channel Islands National Park, it is possible that silts and clays could have been deflated from the Santa Ynez River valley, situated to the north of the Santa Ynez Mountains, and even the Santa Maria River valley, whose westernmost part is in the Santa Maria Basin (Fig. 1). Eolian sand, derived from northwesterly winds, is found on north-south-trending segments of the mainland coastline, well to the north of the Channel Islands, but we are not aware of any observations of significant dust entrainment from the Santa Maria or Santa Ynez River valleys. Nevertheless, a source of eolian silt and clay from these northerly valleys remains as a hypothesis to be tested in the future.

\section{Northwesterly Winds and an Insular-Shelf Source of Dust}

Another potential source of dust from northwesterly winds is the insular shelf that would have been exposed during glacioeustatically lowered sea levels. Studies of well-dated, submerged reefs off Barbados show that sea level 

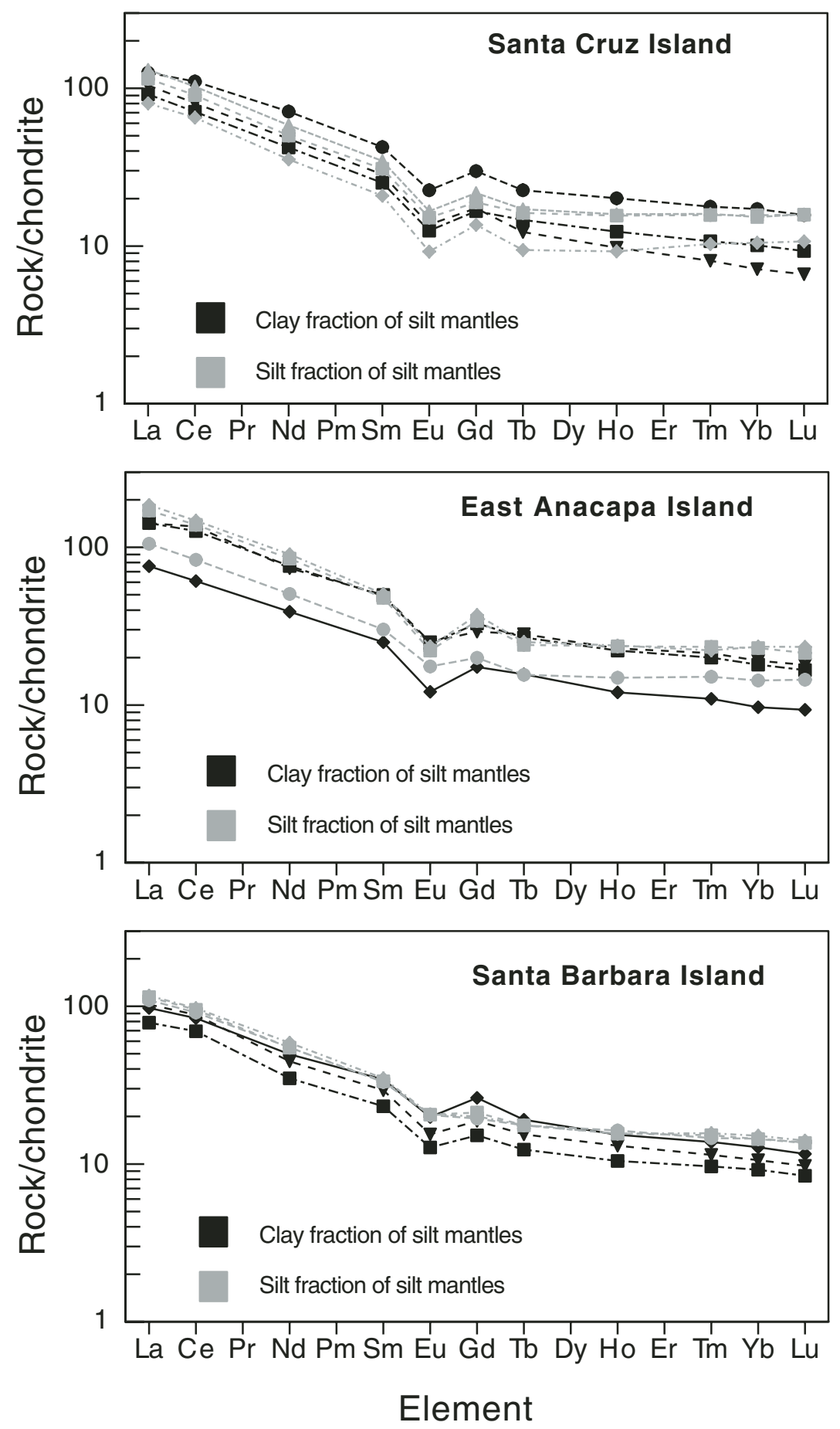

Figure 15. Chondrite-normalized, rare-earth element (REE) plots of silt (53-2 $\mu \mathrm{m})$ and clay $(<2 \mu \mathrm{m})$ fractions of silt mantles on Santa Cruz, East Anacapa, and Santa Barbara Islands.

was $\sim 120 \mathrm{~m}$ below present at the last glacial maximum, ca. 22-21 ka (Bard et al., 1990). On the northern Channel Islands, this magnitude of sea-level lowering would have connected all of the northern islands, and exposed a broad shelf around them, particularly to the north and west also dominate the region today (Fig. 17). Thus, it is possible that finer grained materials may have been deposited from such a source as well.

Several observations argue against an insular-shelf source of dust for the Channel Islands, however. Scholl (1960) studied shelf sediments off Anacapa Island in detail and reported that fine-grained sediments (silts and clays) are rare (see also Fig. 8), and sand-sized shelf sediments are composed largely of either carbonate skeletal grains or volcanic grains derived from the local island bedrock. Although quartz, Kfeldspar, amphibole, and mica are all found in the silt mantles, they are extremely rare in the insular-shelf sediments off Anacapa Island (see Scholl, 1960, his Table 3). On eastern Santa Cruz Island, eolianite (the upper part of the Potato Harbor Formation) appears to be derived from northern shelf sediments, based on its geographic location and dip azimuths. The eolianite facies of the Potato Harbor Formation contains sand-sized particles that are dominated by skeletal carbonate grains $(\sim 70 \%)$, along with locally derived volcanics, Monterey shale, or Santa Cruz Island schist (Weaver and Meyer, 1969). Because San Miguel, Santa Rosa, and eastern Santa Cruz Islands have a variety of sandstones, siltstones, and shales (see, for example, Dibblee and Ehrenspeck, 1998), it is possible that shelf sediments off the western islands may have contributed to the silt mantles on the eastern islands during glacial times.

A more persuasive argument against glacialage shelf sediments being a significant source of particles for silt mantles on the Channel Islands is the presence of silt mantles on Santa Barbara Island. This island has only a very narrow insular shelf and is distant from other insular shelves, both to the north and south. Nevertheless, silt mantles are common on Santa Barbara Island and have close compositional similarities to those on Anacapa and Santa Cruz Island. These observations argue for a common external source, unrelated to the island shelves that would have been exposed during glacial times.

\section{Santa Ana Winds and a Mainland California Source of Dust}

Dust from western North America can be delivered to the eastern Pacific Ocean during "Santa Ana" wind conditions. In contrast to the usual westerly flow of air from the Pacific Ocean to southern California, Santa Ana conditions bring about strong northeasterly winds. Santa Ana winds develop when there is relatively low pressure over the eastern Pacific Ocean off southern California and a high-pressure cell settles in the Great Basin (Fig. 18) after the passage of a cold front (Raphael, 2003; Lu et al., 


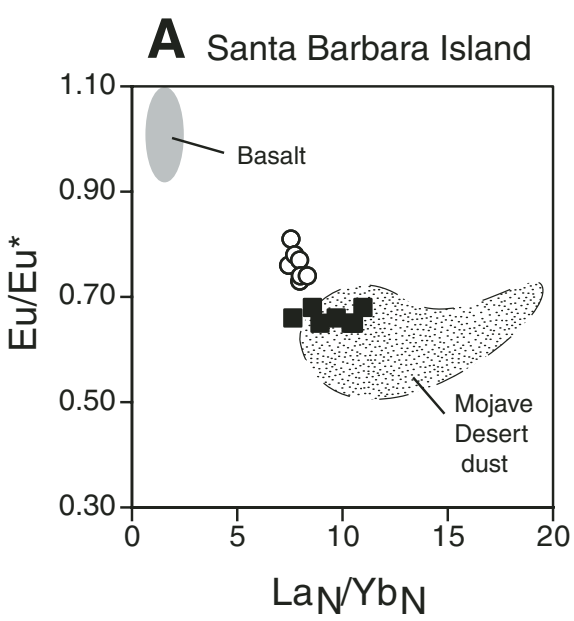

O Silt fraction $(53-2 \mu \mathrm{m})$

- Clay fraction $(<2 \mu \mathrm{m})$
B East Anacapa Island

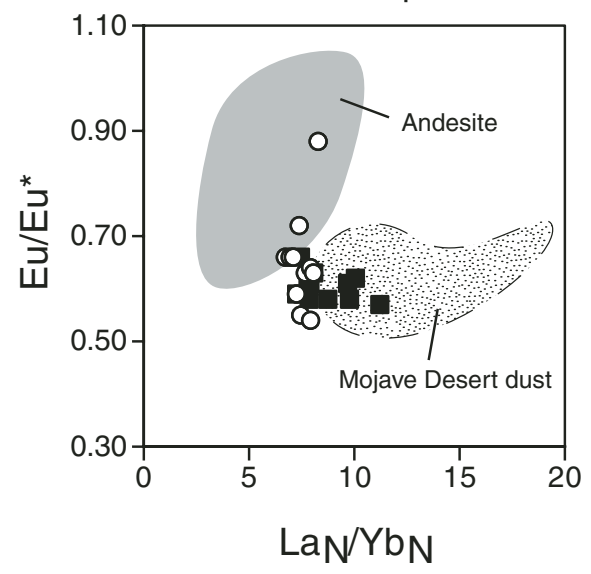

Santa Cruz Island

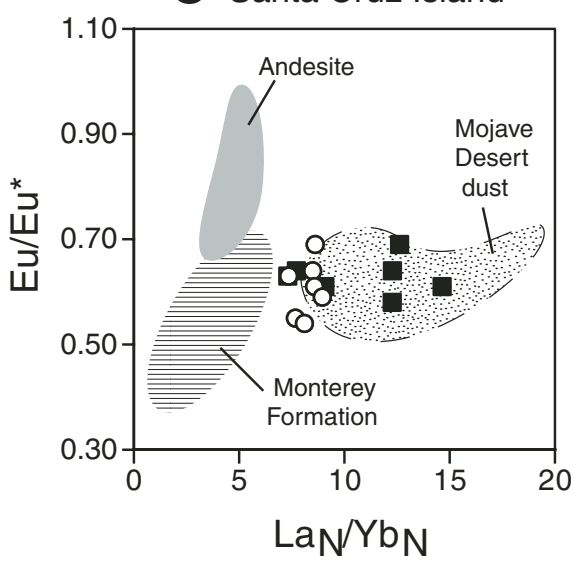

Figure 16. $\mathrm{Eu} / \mathrm{Eu}^{*}$ versus $\mathrm{La}_{\mathrm{N}} / \mathrm{Yb}_{\mathrm{N}}$ values in silt fractions $(53-2 \mu \mathrm{m}$; circles) and clay fractions ( $<2 \mu \mathrm{m}$; solid squares), of silt mantles on (A) Santa Barbara Island, (B) East Anacapa Island, and (C) Santa Cruz Island. Also shown are the ranges in these values for bedrock, consisting of andesite and shale (Santa Cruz Island), basalt (Santa Barbara Island), and andesite (East Anacapa Island). Field defined by Mojave Desert dust collected in traps is from data in Reheis (2003) and Reheis et al. (2002).

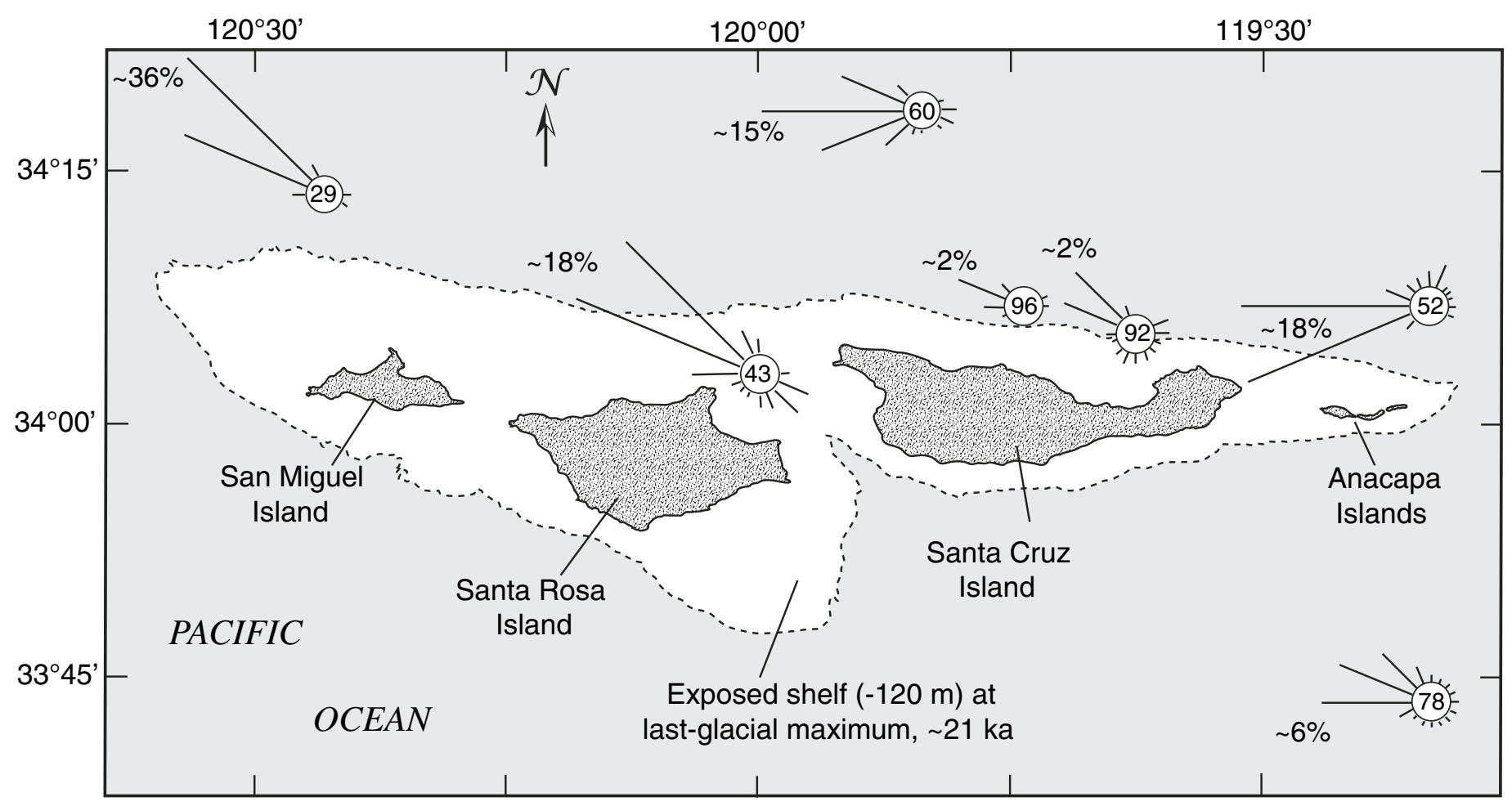

Figure 17. Map of the northern Channel Islands, showing the extent of present offshore shelf that would have been exposed during the last glacial maximum, ca. 21-22 ka, when sea level was lowered $\sim 120 \mathrm{~m}$ (Bard et al., 1990) and wind roses for Channel Islands stations and offshore buoys. Map generated by the authors, using bathymetry from 1:100,000- and 1:250,000-scale U.S. Geological Survey topographic maps. Length of arm is proportional to amount of time that wind is above velocity of $5 \mathrm{~m} / \mathrm{s}$; approximate percentage figure is given for the longest arm; thus, scale for each rose differs. Number in center circle is percent of time that winds are below 5 m/s. Note that periods of record vary for each station, but all are two years or more. Geographic positions of wind roses are approximate for clarity of presentation. Wind roses generated by the authors from data from the Western Regional Climate Center (http://www.wrcc.dri.edu/channel_isl/index.html). 
A

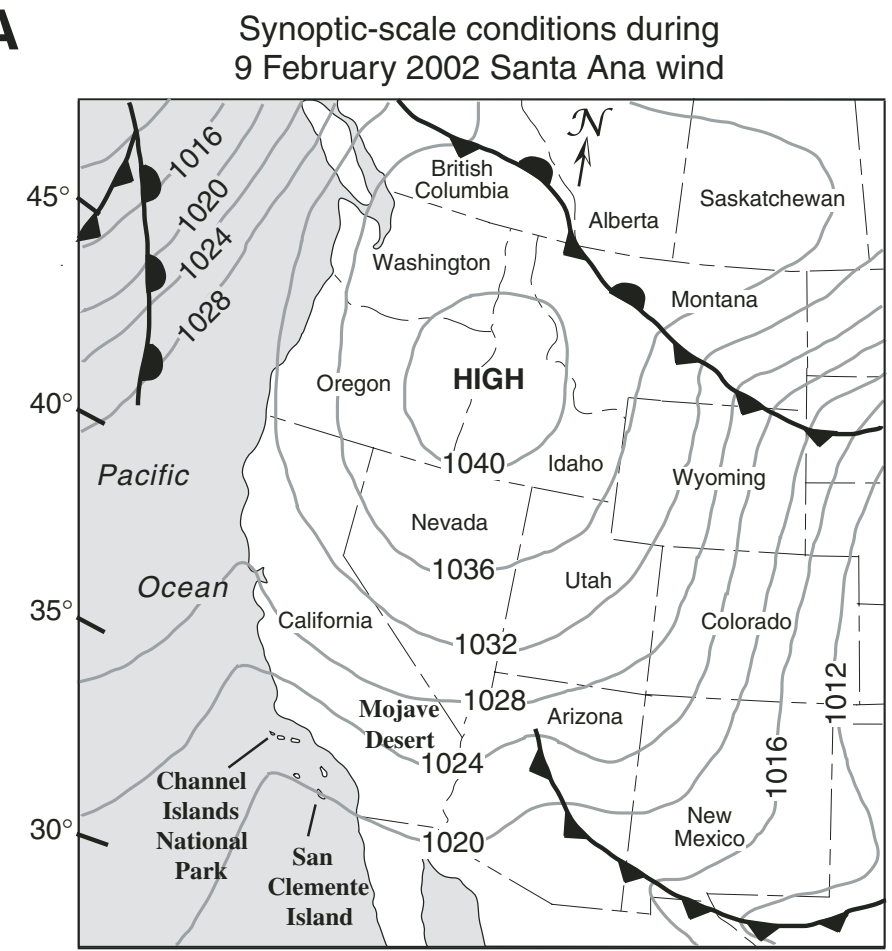

B

Paths of Santa Ana winds and locations of Mojave Desert dust traps

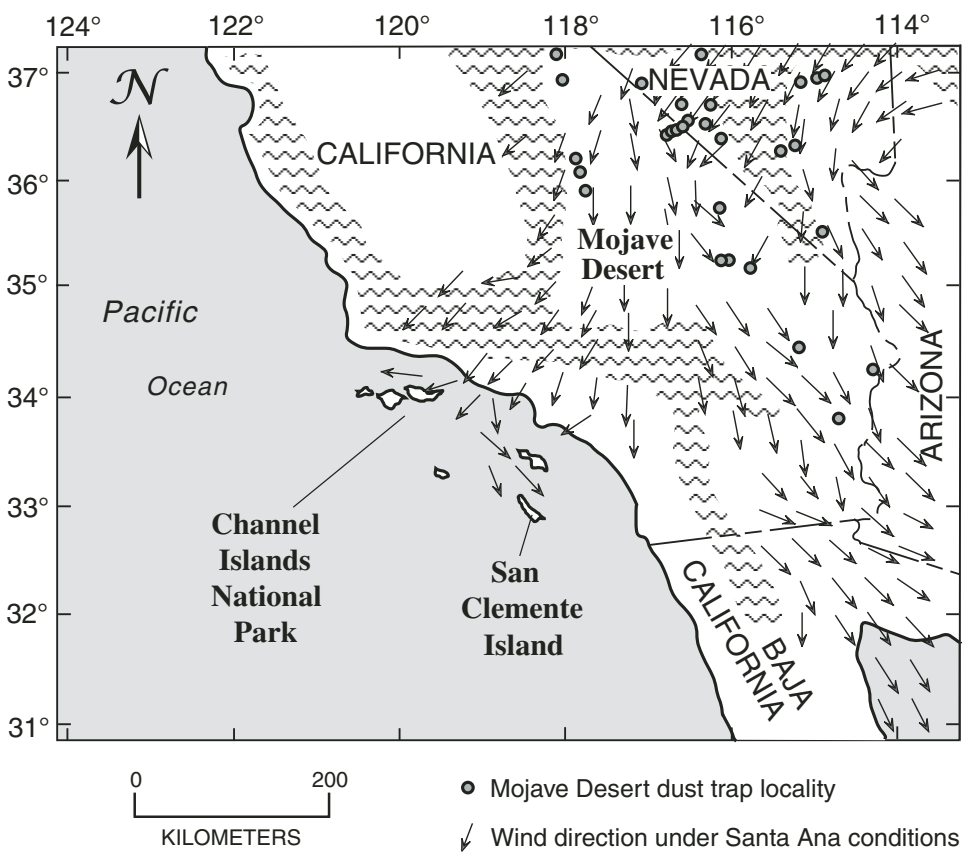

Figure 18. (A) Map of the western United States, showing location of Channel Islands National Park. Also shown are positions of air masses, major fronts, and surface pressures (in millibars) during Santa Ana wind conditions of 9 February 2002. (B) Map of southern California, showing location of Channel Islands National Park and dust trap localities (Reheis, 2003, 2006; Reheis et al., 1995, 2002) in the Mojave Desert. Also shown are patterns of wind direction during "Santa Ana" events. The map of wind directions is simplified from model simulations courtesy of Robert Fovell, Department of Atmospheric and Oceanic Sciences, University of California, Los Angeles (http://www.atmos.ucla.edu/ fovell/ASother/ mm5/SantaAna/winds.html).
2003). The resulting pressure gradient from the Great Basin to the eastern Pacific Ocean results in strong, northerly or northeasterly winds over the Mojave Desert and coastal southern California and Baja California. Santa Ana winds have speeds well in excess of $10 \mathrm{~m} / \mathrm{s}$ and can have gusts as high as $35 \mathrm{~m} / \mathrm{s}$ ( $\mathrm{Hu}$ and Liu, 2003). In a typical year, Santa Ana winds develop several times, starting in fall, peaking in winter, and ending in spring (Raphael, 2003). Nakata et al. (1976) documented observations of Mojave Desert dust plumes developing during Santa Ana wind conditions, using early Landsat imagery. More recent satellite imagery shows the regional nature of dust transport during Santa Ana events (Muhs et al., 2007b)

A previous study also used Landsat imagery to show that dust from the Mojave Desert reaches the southern Channel Islands (Muhs, 1983). The similarities in particle size, mineralogy, and geochemistry of northern Channel Islands silt mantles and Mojave dust is striking and is strong evidence that desert dust is a source. Recent climate modeling shows that the southwestern United States and northwestern Mexico were important sources of dust during the last glacial period (Mahowald et al., 2006). Thus, delivery of eolian silt and clay to the eastern Pacific Ocean, including the Channel Islands, was not necessarily limited to the present or past interglacial periods.

Although the Mojave Desert is a likely source area for fine-grained particles in the silt mantles on soils of Channel Islands National Park, it need not be the only source. The geochemistry of the silts and clays requires only that the source or sources be derived from sediments or rocks with an upper-continental crustal composition. Mojave Desert dust has this composition, but other possible source materials include sediments from river valleys that drain the coastal mountain ranges of southern California and deposit sediment on the continental shelf. In addition to the insular shelves, the continental shelf off mainland southern California was exposed during times of lowered sea level, such as the last glacial period. Fan (1976) shows that the mineralogical compositions of silts in both the Santa Clara River basin, one of the major drainage basins in coastal southern California, and shelf sediments off mainland southern California, are very similar to those of the silt mantles on soils of Channel Islands National Park. Although it appears that northwesterly winds were dominant off southern California during the last glacial period (Johnson, 1977), as they are today (Fig. 17), it is also possible that Santa Ana winds occurred during this period and provided the mechanism for transporting dust from the mainland to the islands. 
Evidence for Eolian Silt and Clay Accumulation in Mainland Southern California Soils

If eolian silt and clay are delivered to Channel Islands National Park from the Mojave Desert, it follows that these particles must also be deposited on soils of mainland southern California. As discussed earlier, in many parts of the Mojave Desert in California, there are numerous occurrences of silt-rich eolian mantles ("Av" horizons) on basaltic volcanic flows or alluvial fan deposits of variable lithologies (Wells et al., 1985; McFadden, 1988; McFadden et al., 1986, 1998; Reheis et al., 1995; Anderson et al., 2002). Farther coastward in southern California, detailed studies of soils developed on Holocene and Pleistocene alluvial terrace deposits in the San Gabriel-San Bernardino Mountains of southern California show good evidence of eolian silt accretion (McFadden and Weldon, 1987; McFadden, 1988). Soils in this area show progressive increases in silt content with terrace age. Chemical weathering of terrace gravels is ruled out as a source of silt because younger gravels are not weathered and older gravels do not weather to anything other than sand. McFadden and Weldon (1987) and McFadden (1988) interpret the progressive increase in silt contents with terrace age as reflecting accumulation of eolian silt over time, derived from the Mojave Desert.

Distinctive silt-rich eolian mantles are not present on top of mainland soils, such as those in the San Gabriel-San Bernardino Mountains. Silt is relatively enriched in surface horizons (McFadden and Weldon, 1987; McFadden, 1988), but silt amounts are usually around $20 \%$ $30 \%$, much lower than on the Channel Islands. Even in the Mojave Desert, silt mantles present as Av horizons typically have only $20 \%-50 \%$ silt (Reheis et al., 1995). Lower silt and higher sand contents in Av horizons of Mojave Desert soils may be explained in part by the proximity of these soils to source areas, where eolian sand contents are expected to be higher. However, farther west, soils with high silt content overall, but without an enriched silt mantle, are comparatively more difficult to explain.

One factor that explains the silt mantles on the islands (and their absence on the mainland) is that the islands have comparatively few burrowing animals (Wenner and Johnson, 1980; Schoenherr et al., 1999). As a prime example, the Botta pocket gopher (Thomomys bottae), one of the major bioturbators of mainland soils, especially along the coast of California, is absent on the islands, and presumably has been absent during the entire time the islands have existed (Johnson, 1983). The role of this animal in homogenizing the fine fraction and small pebbles throughout coastal soils, and concomitantly sorting large clasts into basal stone layers, has been well documented (Johnson, 1989, 1990). Such soils, notably, have not been recorded on the islands. Furthermore, we personally have observed, over many years of working on the islands, that other less obvious, though important, soil bioturbators, the array of invertebrate fauna normally encountered in mainland soils, are notably few on the islands. Thus, preservation of silt-rich eolian mantles on the Channel Islands likely reflects the dearth of burrowing taxa.

\section{SUMMARY AND CONCLUSIONS}

We conclude that silt-rich surface horizons of soils on Santa Cruz, Anacapa, and Santa Barbara Islands, Channel Islands National Park, are eolian, the result of wind transport of particles from a distant source. Silt mantles on clay-rich Vertisols have not been reported on the mainland, despite the ubiquity of this soil type in California. This suggests that the silt mantles have a geologic, rather than a pedogenic, origin. The mean particle size of the mantles is distinctly finer than eolian sand, but is similar to loess and closely overlaps the range of particle sizes for Mojave Desert dust. As such, these eolian silt mantles are intermediate members of a continuum of eolian influences on soils. The mineralogy of the silt mantles is dominated by quartz in the silt fractions and mica in the clay fractions. Both quartz and mica are rare or absent altogether from the volcanic rocks that constitute the only bedrock on Anacapa and Santa Barbara Islands. The relative abundances of Sc-Th-La and Ta-Nd-Cr show that the silts and clays in the surface mantles are not derived from volcanic rocks on any of the three islands, or in the case of Santa Cruz Island, from Monterey shale. However, the relative abundance of these elements in the island silts and clays is similar to that in Mojave Desert dust, supporting a mainlandderived eolian origin, or at least a source with an upper-crustal composition. Island shelves could have been a source of dust during glacioeustatically lowered sea levels, but particle-size and mineralogical data from the modern island shelf sediments are not consistent with this source. However, dust can be delivered to the eastern Pacific Ocean from mainland California and Baja California during Santa Ana wind events, after high pressure develops in the Great Basin following the passage of a cold front. The ultimate source of the dust is uncertain and could be the Mojave Desert, the mainland California shelf during lowered sea levels, or some combination of these sources.
Identification of eolian silt mantles on soils of Channel Islands National Park has several important implications. The favorable particle-size and moisture-holding capacity of the silt mantles may be significant as a medium of growth for numerous island endemic plants, many of which are rare or endangered. Eolian soil "renewal" is particularly significant for island landscapes that have undergone severe soil erosion due to many decades of grazing and feral animal activity. If eolian silt is delivered to islands offshore, then it follows that it is also delivered to the surrounding ocean. Thus, eolian silt and clay could be more significant components of the ocean-sediment budget than previously suspected and may provide key elements for growth of primary producers, such as phytoplankton. Because of the possible biogeochemical and climatic effects of dust delivery to the ocean, more study is needed to ascertain whether North America is providing a significant amount of eolian dust to the eastern Pacific Ocean.

\section{ACKNOWLEDGMENTS}

The work in this study was supported by the Earth Surface Dynamics Program of the U.S. Geological Survey and is a contribution to the "Eolian History of North America" and "Effects of Climatic Variability and Land Use on American Drylands" projects. We extend our sincere appreciation to Kate Faulkner, U.S. National Park Service (NPS), and Channel Islands National Park, for permission to collect soils on the islands and for essential logistical support. Boat skippers Keith Duran and Mike Alfred (NPS) and biologist Paige Martin (NPS) kindly allowed us to join them on a special trip to Santa Barbara Island to collect soils. We also thank biologist Dirk Rodriguez (NPS), who identified plants for us. We thank Robert Fovell (UCLA) for allowing us to redraw his maps of Santa Ana wind patterns. Special thanks to Linda Gundersen, Tom Armstrong, Randy Schumann, and Scott Minor (all U.S. Geological Survey), who took time from busy schedules to visit Channel Islands National Park and give us valuable feedback. We appreciate the insightful reviews of an earlier draft of this paper by Natalie Mahowald, Kathleen Simmons, Sam Marx, Peter Jacobs, and Diana Johnson.

\section{REFERENCES CITED}

Anderson, K., Wells, S., and Graham, R., 2002, Pedogenesis of vesicular horizons, Cima Volcanic Field, Mojave Desert, California: Soil Science Society of America Journal, v. 66 , p. $878-887$.

Bard, E., and Hamelin, B., Fairbanks, R.G., and Zindler, A., 1990 , Calibration of the ${ }^{14} \mathrm{C}$ timescale over the past 30,000 years using mass spectrometric U-Th ages from Barbados corals: Nature, v. 345, p. 405-410.

Bettis, E.A., III, Muhs, D.R., Roberts, H.M., and Wintle, A.G., 2003, Last glacial loess in the conterminous U.S.A: Quaternary Science Reviews, v. 22, p. $1907-$ 1946, doi: 10.1016/S0277-3791(03)00169-0.

Bhatia, M.R., and Crook, K.A.W., 1986, Trace element characteristics of graywackes and tectonic setting discrimination of sedimentary basins: Contributions to Mineralogy and Petrology, v. 92, p. 181-193, doi: 10.1007/BF00375292.

Birkeland, P.W., 1999, Soils and geomorphology: London, Oxford University Press, $430 \mathrm{p}$. 
Budahn, J.R., and Wandless, G.A., 2002, Instrumental neutron activation by long count: U.S. Geological Survey Open-File Report, OF 02-0223, p. X1-X13.

Butterworth, J.B., Jones, J.A., and Jones, S., 1993, Soil forming factors, morphology and classification-Santa Cruz Island, California, in Hochberg, F.G., ed., Third California Islands Symposium: Santa Barbara, California, Santa Barbara Museum of Natural History, p. 39-44.

Coudé-Gaussen, G., 1990, The loess and loess-like deposits along the sides of the western Mediterranean Sea Genetic and palaeoclimatic significance: Quaternary International, v. 5, p. 1-8, doi: 10.1016/10406182(90)90020-5.

Chadwick, O.A., Derry, L.A., Vitousek, P.M., Huebert, B.J., and Hedin, L.O., 1999, Changing sources of nutrients during four million years of ecosystem development Nature, v. 397, p. 491-497, doi: 10.1038/17276.

Dibblee, T.W., Jr., 2001a, Geologic map of Anacapa and Santa Barbara Islands, Channel Islands National Park, Ventura and Santa Barbara Counties, California: Santa Barbara, California, Dibblee Geological Foundation Map DF-73, scale 1:24,000

Dibblee, T.W., Jr., 2001b, Geologic map of eastern Santa Cruz Island, Santa Barbara County, California: Santa Barbara, California, Dibblee Geological Foundation Map DF-78, scale 1:24,000

Dibblee, T.W., Jr., and Ehrenspeck, H.E., 1998, General geology of Santa Rosa Island, California, in Weigand, P.W., ed., Contributions to the geology of the Northern Channel Islands, southern California: Bakersfield California, American Association of Petroleum Geologists, Pacific Section, MP-45, p. 49-75.

Eden, D.N., and Hammond, A.P., 2003, Dust accumulation in the New Zealand region since the Last Glacial Maximum: Quaternary Science Reviews, v. 22, p. 2037 2052, doi: 10.1016/S0277-3791(03)00168-9.

Falkowski, P.G., Barber, R.T., and Smetacek, V., 1998, Biogeochemical controls and feedbacks on ocean primary production: Science, v. 281, p. 200-206, doi: 10.1126/ science.281.5374.200.

Fan, P.-F., 1976, Recent silts in the Santa Clara River drainage basin, southern California: A mineralogical investigation of their origin and evolution: Journal of Sedimentary Petrology, v. 46, p. 802-812.

Fanning, D.S., and Keramidas, V.Z., 1977, Micas, in Dixon, J.B., and Weed, S.B., eds., Minerals in soil environments: Madison, Wisconsin, USA, Soil Science Society of America, p. 195-258.

Gallet, S., Jahn, B., Van Vliet-Lanoe, B., Dia, A., and Rossello, E.A., 1998, Loess geochemistry and its implications for particle origin and composition of the upper continental crust: Earth and Planetary Science Letters, v. 156, p. 157-172, doi: 10.1016/S0012-821X(97)00218-5.

Gile, L.H., and Grossman, R.B., 1979, The desert project soil monograph: U.S. Department of Agriculture, Soil Conservation Service, 984 p.

Harrison, S.P., Kohfeld, K.E., Roelandt, C., and Claquin, T., 2001, The role of dust in climate changes today, at the last glacial maximum and in the future: Earth-Science Reviews, v. 54, p. 43-80, doi: 10.1016/S00128252(01)00041-1.

Herwitz, S.R., Muhs, D.R., Prospero, J.M., Mahan, S., and Vaughn, B., 1996, Origin of Bermuda's clay-rich Quaternary paleosols and their paleoclimatic significance: Journal of Geophysical Research, v. 101, p. 23,38923,400, doi: 10.1029/96JD02333.

Hesse, P.P., and McTainsh, G.H., 2003, Australian dust deposits: Modern processes and the Quaternary record: Quaternary Science Reviews, v. 22, p. 2007-2035, doi: 10.1016/S0277-3791(03)00164-1.

$\mathrm{Hu}, \mathrm{H}$. , and Liu, W.T., 2003, Oceanic thermal and biological responses to Santa Ana winds: Geophysical Research Letters, v. 30, no. 11, 1596, doi 10.1029/2003GL017208

Husar, R.B., 28 others, 2001, Asian dust events of April 1998: Journal of Geophysical Research, v. 106, p. 18317 18330, doi: 10.1029/2000JD900788.

Jackson, M.L., Levelt, T.W.M., Syers, J.K., Rex, R.W., Clayton, R.N., Sherman, G.D., and Uehara, G., 1971 , Geomorphological relationships of troposphericallyderived quartz in the souls of the Hawaiian Islands: Soil Science Society of America Proceedings, v. 35, p. 515-525.
Jackson, M.L., Gibbons, F.R., Syers, J.K., and Mokma, D.L., 1972, Eolian influence on soils developed in a chronosequence of basalts in Victoria, Australia: Geoderma, v. 8, p. 147-163, doi: 10.1016/0016-7061(72)90043-2.

Jahn, B., Gallet, S., and Han, J., 2001, Geochemistry of the Xining, Xifeng and Jixian sections, Loess Plateau of China: Eolian dust provenance and paleosol evolution during the last $140 \mathrm{ka}$ : Chemical Geology, v. 178, p. 71-94, doi: 10.1016/S0009-2541(00)00430-7.

Jickells, T.D., An, Z.S., Andersen, K.K., Baker, A.R., Bergametti, G., Brooks, N., Cao, J.J., Boyd, P.W., Duce, R.A., Hunter, K.A., Kawahata, H., Kubilay, N., LaRoche, J., Liss, P.S., Mahowald, N., Prospero, J.M. Ridgwell, A.J., Tegen, I., and Torres, R., 2005, Global iron connections between desert dust, ocean biogeochemistry, and climate: Science, v. 308, p. 67-71, doi 10.1126/science. 1105959 .

Johnson, D.L., 1977, The late Quaternary climate of coastal California: Evidence for an Ice Age refugium: Quaternary Research, v. 8, p. 154-179, doi: 10.1016/00335894(77)90043-6.

Johnson, D.L., 1979, Geology, soils, and erosion, in Power, D.M., ed., Natural resources study of the Channel Islands National Monument, California: Santa Barbara, California, Santa Barbara Museum of Natural History, p. 3.1-3.73.

Johnson, D.L., 1980, Episodic vegetation stripping, soil erosion, and landscape modification in prehistoric and recent time, San Miguel Island, California, in Power, D.M., ed., The California Islands: Proceedings of Multidisciplinary Symposium: Santa Barbara, California, Santa Barbara Museum of Natural History, p. 103-121.

Johnson, D.L., 1983, The California continental borderland: Landbridges, watergaps and biotic dispersals, in Masters, P.M., and Flemming, N.C., eds., Quaternary coastlines and marine archaeology: London, Academic Press, p. 481-527.

Johnson, D.L., 1989, Subsurface stone lines, stone zones, artifact-manuport layers, and biomantles produced by bioturbation via pocket gophers (Thomomys bottae): American Antiquity, v. 54, p. 370-389, doi: $10.2307 / 281712$

Johnson, D.L., 1990, Biomantle evolution and the redistribution of earth materials and artifacts: Soil Science, v. 149 , p. 84-102, doi: 10.1097/00010694-19900200000004

Jones, J.A., and Grice, D., 1993, A computer-generated soils map of Santa Cruz Island, California, in Hochberg, F.G., ed., Third California Islands Symposium: Santa Barbara, California, Santa Barbara Museum of Natural History, p. $45-56$

Kohfeld, K.E., and Harrison, S.P., 2001, DIRTMAP: The geological record of dust: Earth-Science Reviews, v. 54 , p. $81-114$.

Le Bas, M.J., Le Maitre, R.W., and Woolley, A.R., 1992, The construction of the total alkali-silica chemical classification of volcanic rocks: Mineralogy and Petrology, v. 46, p. 1-22, doi: 10.1007/BF01160698

Le Bas, M.J., Le Maitre, R.W., Streckeisen, A., and Zanettin, B., 1986, A chemical classification of volcanic rocks based on the total alkali-silica diagram: Journal of Petrology, v. 27, p. 745-750.

Lipps, J.H., Valentine, J.W., and Mitchell, E., 1968, Pleistocene paleoecology and biostratigraphy, Santa Barbara Island, California: Journal of Paleontology, v. 42, p. 291-307.

Livingstone, I., Bullard, J.E., Wiggs, G.F.S., and Thomas, D.S.G., 1999, Grain-size variation on dunes in the southwest Kalahari, southern Africa: Journal of Sedimentary Research, v. 69 , p. $546-552$.

Lu, H., Vandenberghe, J., and An, Z., 2001, Aeolian origin and palaeoclimatic implications of the "red clay" (north China) as evidenced by grain-size distribution: Journal of Quaternary Science, v. 16, p. 89-97, doi: 10.1002/1099-1417(200101)16:1<89::AIDJQS578>3.0.CO;2-8.

Lu, R., Turco, R.P., Stolzenbach, K., Friedlander, S.K, Xiong, C., Schiff, K., Tiefenthaler, L., and Wang, G., 2003, Dry deposition of airborne trace metals on the Los Angeles Basin and adjacent coastal waters: Journal of Geophysical Research, v. 108, 4074, doi: 10.1029/2001JD001446, doi: 10.1029/2001JD001446.
Luyendyk, B.P., Gans, P.B., and Kamerling, M.J., 1998, ${ }^{40} \mathrm{Ar} /{ }^{39} \mathrm{Ar}$ geochronology of southern California Neogene volcanism, in Weigand, P.W., ed., Contributions to the geology of the Northern Channel Islands, southern California: Bakersfield, California, American Association of Petroleum Geologists, Pacific Section, MP-45, p. 9-35.

Mahowald, N., Kohfeld, K., Hansson, M., Balkanski, Y., Harrison, S.P., Prentice, I.C., Schulz, M., and Rodhe, H., 1999, Dust sources and deposition during the last glacial maximum and current climate: A comparison of model results with paleodata from ice cores and marine sediments: Journal of Geophysical Research, v. 104, p. 15,895-15,916, doi: 10.1029/1999JD900084.

Mahowald, N., Muhs, D.R., Levis, S., Rasch, P.J., Yoshioka, M., Zender, C.S., and Luo, C., 2006, Change in atmospheric mineral aerosols in response to climate: Last glacial period, pre-industrial, modern and doubled carbon dioxide climates: Journal of Geophysical Research, v. 111, D10202, doi: 10.1029/2005JD006653.

McFadden, L.D., 1988, Climatic influences on rates and processes of soil development in Quaternary deposits of southern California: Geological Society of America Special Paper 216, p. 153-177.

McFadden, L.D., and Weldon, R.J., III, 1987, Rates and processes of soil development on Quaternary terraces in Cajon Pass, California: Geological Society of America Bulletin, v. 98 , p. 280-293, doi: $10.1130 / 0016$ 7606(1987)98<280:RAPOSD>2.0.CO;2.

McFadden, L.D., Wells, S.G., and Dohrenwend, J.C., 1986, Influences of Quaternary climatic changes on processes of soil development on desert loess deposits of the Cima volcanic field, California: Catena, v. 13, p. 361-389, doi: 10.1016/0341-8162(86)90010-X.

McFadden, L.D., McDonald, E.V., Wells, S.G., Anderson, K., Quade, J., and Forman, S.L., 1998, The vesicular layer and carbonate collars of desert soils and pavements: Formation, age and relation to climate change: Geomorphology, v. 24, p. 101-145, doi: 10.1016/S0169-555X (97)00095-0

McLennan, S.M., 1989, Rare earth elements in sedimentary rocks: Influence of provenance and sedimentary processes: Reviews in Mineralogy, v. 21, p. 169-200.

Muhs, D.R., 1982, A soil chronosequence on Quaternary marine terraces, San Clemente Island, California: Geoderma, v. 28, p. 257-283, doi: 10.1016/0016-7061(82) 90006-4.

Muhs, D.R., 1983, Airborne dust fall on the California Channel Islands, U.S.A: Journal of Arid Environments, v. 6, p. 223-238.

Muhs, D.R., 2002, Evidence for the timing and duration of the last interglacial period from high-precision uranium-series ages of corals on tectonically stable coastlines: Quaternary Research, v. 58, p. 36-40, doi: 10.1006/qres.2002.2339

Muhs, D.R., and Benedict, J.B., 2006, Eolian additions to late Quaternary alpine soils, Indian Peaks Wilderness Area, Colorado Front Range: Arctic, Antarctic, and Alpine Research, v. 38, p. 120-130, doi: 10.1657/15230430(2006)038[0120:EATLQA]2.0.CO;2.

Muhs, D.R., and Bettis, E.A., III, 2000, Geochemical variations in Peoria loess of western Iowa indicate paleowinds of midcontinental North America during last glaciation: Quaternary Research, v. 53, p. 49-61, doi: 10.1006/qres.1999.2090

Muhs, D.R., and Budahn, J.R., 2006, Geochemical evidence for the origin of late Quaternary loess in central Alaska: Canadian Journal of Earth Sciences, v. 43, p. 323-337, doi: 10.1139/E05-115

Muhs, D.R., Simmons, K.R., Kennedy, G.L., and Rockwell, T.K., 2002, The last interglacial period on the Pacific Coast of North America: Timing and paleoclimate: Geological Society of America Bulletin, v. 114, p. 569-592, doi: 10.1130/0016-7606(2002)114<0569: TLIPOT>2.0.CO;2.

Muhs, D.R., McGeehin, J.P., Beann, J., and Fisher, E., 2004a, Holocene loess deposition and soil formation as competing processes, Matanuska Valley, southern Alaska: Quaternary Research, v. 61, p. 265-276, doi: 10.1016/j.yqres.2004.02.003.

Muhs, D.R., Wehmiller, J.F., Simmons, K.R., and York, L.L., 2004b, Quaternary sea level history of the United States, in Gillespie, A.R., Porter, S.C., and Atwater, B.F., eds., 
The Quaternary period in the United States: Amsterdam, Elsevier, p. 147-183.

Muhs, D.R., Simmons, K.R., Kennedy, G.L., Ludwig, K.R. and Groves, L.T., 2006, A cool eastern Pacific Ocean at the close of the last interglacial complex: Quaternary Science Reviews, v. 25, p. 235-262, doi: 10.1016/ j.quascirev.2005.03.014.

Muhs, D.R., Budahn, J., Prospero, J.M., and Carey, S.N., 2007a, Geochemical evidence for African dust inputs to soils of western Atlantic islands: Barbados, the Bahamas and Florida: Journal of Geophysical Research, v. 112, F02009, doi: 10.1029/2005JF000556.

Muhs, D.R., Budahn, J., Reheis, M., Beann, J., Skipp, G., and Fisher, E., 2007b, Airborne dust transport to the eastern Pacific Ocean off southern California: Evidence from San Clemente Island: Journal of Geophysical Research,v. 112, D13203, doi: 10.1029/2006 JD007577.

Nakata, J.K., Wilshire, H.G., and Barnes, G.G., 1976, Origin of Mojave Desert dust plumes photographed from space: Geology, v. 4, p. 644-648, doi: 10.1130/00917613(1976)4<644:OOMDDP>2.0.CO;2.

Norris, R.W., 1995, Little Anacapa Island: California Geology, v. 48, p. 3-9.

Olivarez, A.M., Owen, R.M., and Rea, D.K., 1991, Geochemistry of eolian dust in Pacific pelagic sediments: Implications for paleoclimatic interpretations: Geochimica et Cosmochimica Acta, v. 55, p. 2147-2158, doi 10.1016/0016-7037(91)90093-K.

Olmsted, F.H., 1958, Geologic reconnaissance of San Clemente Island, California: U.S. Geological Survey Bulletin 1071-B, $68 \mathrm{p}$.

Pinter, N., Sorlien, C.C., and Scott, A.T., 2003, Fault-related fold growth and isostatic subsidence, California Channel Islands: American Journal of Science, v. 303, p. 300-318, doi: 10.2475/ajs.303.4.300.

Pinter, N., Lueddecke, S.B., Keller, E.A., and Simmons, K.R., 1998, Late Quaternary slip on the Santa Cruz Island fault, California: Geological Society of America Bulletin, v. 110, p. 711-722, doi: 10.1130/00167606(1998)110<0711:LQSOTS>2.3.CO;2.

Prospero, J.M., and Lamb, P.J., 2003, African droughts and dust transport to the Caribbean: Climate change implications: Science, v. 302, p. 1024-1027, doi: 10.1126/ science. 1089915.

Prospero, J.M., Ginoux, P., Torres, O., Nicholson, S.E., and Gill, T.E., 2002, Environmental characterization of global sources of atmospheric soil dust identified with the Nimbus 7 Total Ozone Mapping Spectrometer (TOMS) absorbing aerosol product: Reviews of Geophysics, v. 40, no. 1, 1002, doi: 10.1029/2000RG000095.

Raphael, M.N., 2003, The Santa Ana winds of California: Earth Interactions, v. 7, no. 8, p. 1-13, doi: 10.1175 / 1087-3562(2003)007<0001:TSAWOC >2.0.CO;2.

Rea, D.K., 1994, The paleoclimatic record provided by eolian deposition in the deep sea: The geologic history of wind: Reviews of Geophysics, v. 32, p. 159-195, doi: $10.1029 / 93 R G 03257$

Reheis, M.C., 2003, Dust deposition in Nevada, California, and Utah, 1984-2002: U.S. Geological Survey OpenFile Report 03-138, version 1.0 (http://pubs.usgs.gov/ of/2003/ofr-03-138/).

Reheis, M.C., 2006, A 16-year record of eolian dust in southern Nevada and California, USA: Controls on dust generation and accumulation: Journal of Arid Environments, v. 67 , p. 487-520, doi: 10.1016/j.jaridenv. 2006.03.006.

Reheis, M.C., and Kihl, R., 1995, Dust deposition in southern Nevada and California, 1984-1989: Relations to climate, source area, and source lithology: Journal of Geophysical Research, v. 100 , p. 8893-8918, doi: $10.1029 /$ 94JD03245.

Reheis, M.C., Budahn, J.R., and Lamothe, P.J., 2002, Geochemical evidence for diversity of dust sources in the southwestern United States: Geochimica et Cosmochimica Acta, v. 66, p. 1569-1587, doi: 10.1016/S00167037(01)00864-X.
Reheis, M.C., Goodmacher,J.C., Harden, J.W., McFadden, L.D., Rockwell, T.K., Shroba, R.R., Sowers, J.M., and Taylor, E.M. 1995, Quaternary soils and dust deposition in southern Nevada and California: Geological Society of America Bulletin, v. 107 , p. 1003-1022, doi: 10.1130/00167606(1995)107<1003:QSADDI >2.3.CO;2.

Rex, R.W., Syers, J.K., Jackson, M.L., and Clayton, R.N., 1969, Eolian origin of quartz in soils of Hawaiian islands and in Pacific pelagic sediments: Science, v. 163 , p. $277-279$, doi: $10.1126 /$ science. 163.3864 .277 .

Reynolds, R., Belnap, J., Reheis, M., Lamothe, P., and Luiszer, F., 2001, Aeolian dust in Colorado Plateau soils: Nutrient inputs and recent change in source: Proceedings of the National Academy of Sciences of the United States of America, v. 98, p. 7123-7127, doi: 10.1073/pnas.121094298.

Reynolds, R., Neff, J., Reheis, M., and Lamothe, P., 2006, Atmospheric dust in modern soil on aeolian sandstone, Colorado Plateau (USA): Variation with landscape position and contribution to potential plant nutrients: Geoderma, v. 130, p. 108-123, doi: 10.1016/ j.geoderma.2005.01.012.

Rognon, R., and Coudé-Gaussen, G., 1987, Reconstitution paléoclimatique à partir des sédiments du Pleistocène supérieur et de l'Holocène du Nord de Fuerteventura (Canaries): Zeitschrift für Geomorphologie N.F., v. 31, p. 1-19.

Rosentreter, R., and Belnap, J., 2001, Biological soil crusts of North America, in Belnap, J., and Lange, O.L., eds., Biological soil crusts: Structure, function, and management: Berlin, Springer, p. 31-50.

Schoenherr, A.A., Feldmeth, C.R., and Emerson, M.J., 1999, Natural history of the islands of California: Berkeley, University of California Press, $502 \mathrm{p}$.

Scholl, D.W., 1960, Relationship of the insular shelf sediments to the sedimentary environments and geology of Anacapa Island, California: Journal of Sedimentary Petrology, v. 30, p. 123-139.

Scott, A.T., and Pinter, N., 2003, Extraction of coastal terraces and shoreline-angle elevations from digital terrain models, Santa Cruz and Anacapa Islands, California: Physical Geography, v. 24, p. 271-294.

Soil Survey Staff, Natural Resources Conservation Service, U.S. Department of Agriculture, 2006, Official soil series descriptions: Available online, http://soils.usda. gov/technical/classification/osd/index.html.

Sun, J., 2002, Source regions and formation of the loess sediments on the high mountain regions of northwestern China: Quaternary Research, v. 58, p. 341-351, doi: 10.1006/qres.2002.2381.

Swap, R., Garstang, M., Greco, S., Talbot, R., and Kållberg, P., 1992, Saharan dust in the Amazon Basin Tellus, v. 44B, p. 133-149.

Taylor, S.R., and McLennan, S.M., 1985, The continental crust: Its composition and evolution: Oxford, Blackwell, $312 \mathrm{p}$.

Taylor, S.R., and McLennan, S.M., 1995, The geochemical evolution of the continental crust: Reviews of Geophysics, v. 33, p. 241-265, doi: 10.1029/95RG00262.

Taylor, S.R., McLennan, S.M., and McCulloch, M.T., 1983, Geochemistry of loess, continental crustal composition and crustal model ages: Geochimica et Cosmochimica Acta, v. 47, p. 1897-1905, doi: 10.1016/00167037(83)90206-5.

Tegen, I., 2003, Modeling the mineral dust aerosol cycle in the climate system: Quaternary Science Reviews, v. 22, p. 1821-1834, doi: 10.1016/S0277-3791(03)00163-X.

Tratt, D.M., Frouin, R.J., and Westphal, D.L., 2001, 1998 Asian dust event: A southern California perspective: Journal of Geophysical Research, v. 106, p. 18,37118,379, doi: 10.1029/2000JD900758

Valentine, J.W., and Lipps, J.H., 1963, Late Cenozoic rockyshore assemblages from Anacapa Island, California: Journal of Paleontology, v. 37, p. 1292-1302.

Vedder, J.G., and Norris, R.M., 1963, Geology of San Nicolas Island, California: U.S. Geological Survey Professional Paper 369, $65 \mathrm{p}$.
Wang, X., Dong, Z., Zhang, J., and Zhao, A., 2002, Relations between morphology, air flow, sand flux and particle size on transverse dunes, Taklimakan Sand Sea, China: Earth Surface Processes and Landforms, v. 27, p. 515-526, doi: 10.1002/esp.324.

Weaver, D.W., and Meyer, G.L., 1969, Stratigraphy of northeastern Santa Cruz Island, in Weaver, D.W., ed., Geology of the Northern Channel Islands: Association of American Petroleum Geologists-Society of Economic Paleontologists and Mineralogists, Pacific Sections, Special Publication, p. 95-104.

Weigand, P.W., 1993, Geochemistry and origin of middle Miocene volcanic rocks from Santa Cruz and Anacapa Islands, Southern California Borderland, in Hochberg, F.G., ed., Third California Islands Symposium: Santa Barbara, California, Santa Barbara Museum of Natural History, p. 21-37.

Weigand, P.W., and Savage, K.L., 2002, Summary of the Miocene igneous rocks of the Channel Islands, southern California, in Browne, D.R., Mitchell, K.L., and Chaney, H.W., eds., Proceedings of the Fifth California Islands Symposium, v. 1: Santa Barbara, California, Santa Barbara Museum of Natural History, p. 106-114.

Weigand, P.W., Savage, K.L., and Nicholson, C., 2002, The Conejo Volcanics and other Miocene volcanic suites in southwestern California: Geological Society of America Special Paper 365, p. 187-204.

Weigand, P.W., Savage, K.L., Reid, T., and Chinn, B., 1998, Composition of volcanic rocks on Santa Rosa, San Miguel, and Santa Barbara Islands, California, in Weigand, P.W., ed., Contributions to the geology of the Northern Channel Islands, southern California: Bakersfield, California, American Association of Petroleum Geologists, Pacific Section, MP-45, p. 37-47.

Wells, S.G., McFadden, L.D., Dohrenwend, J.C., Turrin, B.D., and Mahrer, K.D., 1985, Late Cenozoic landscape evolution of lava flow surfaces of the Cima volcanic field, Mojave Desert, California: Geological Society of America Bulletin, v. 96, p. 1518-1529, doi: 10.1130/00167606(1985)96<1518:LCLEOL >2.0.CO;2.

Wenner, A.M., and Johnson, D.L., 1980, Land vertebrates on the California Channel Islands: Sweepstakes or bridges?, in Power, D.M., ed., The California Islands: Proceedings of a Multidisciplinary Symposium: Santa Barbara, California, Santa Barbara Museum of Natural History, p. 497-530.

Yaalon, D.H., and Ganor, E., 1973, The influence of dust on soils during the Quaternary: Soil Science, v. 116, p. 146-155, doi: 10.1097/00010694-197309000-00003.

Zárate, M.A., 2003, Loess of southern South America: Quaternary Science Reviews, v. 22, p. 1987-2006, doi: 10.1016/S0277-3791(03)00165-3.

Zhang, K.-J., 2004, Secular geochemical variations in the Lower Cretaceous siliciclastic rocks from central Tibet (China) indicate a tectonic transition from continental collision to back-arc rifting: Earth and Planetary Science Letters, v. 229, p. 73-89, doi: 10.1016/ j.eps1.2004.10.030.

Zöller, L., von Suchodoletz, H., and Küster, N., 2003, Geoarchaeological and chronometrical evidence of early human occupation on Lanzarote (Canary Islands): Quaternary Science Reviews, v. 22, p. 1299-1307, doi: 10.1016/S0277-3791(03)00042-8.

Zöller, L., von Suchodoletz, H., Blanchard, H., Faust, D., and Hambach, U., 2004, Reply to the comment by J.C. Carracedo et al. on "Geoarchaeological and chronometrical evidence of early human occupation on Lanzarote (Canary Islands)": Quaternary Science Reviews, v. 23, p. 2049-2052, doi: 10.1016/j.quascirev.2004.02.011.

ManUSCRIPT ReCEIVEd 9 MARCH 2007

Revised Manuscript Received 22 June 2007

MANUSCRIPT ACCEPTED 25 JunE 2007

Printed in the USA 